Citation: Vieira, A.S., Stewart, R.A. Beal, C.D. (2015) Air source heat pump water heaters in residential buildings in Australia: Identification of key performance parameters. Buildings and Energy, 91, 148-162. doi:10.1016/j.enbuild.2015.01.041

\title{
Air source heat pump water heaters in residential buildings in Australia: Identification of key performance parameters
}

\author{
Abel S. Vieira ${ }^{\mathrm{a}}$, Rodney A. Stewart ${ }^{\mathrm{a}}$ and Cara D. Beal ${ }^{\mathrm{b}}$ \\ ${ }^{a}$ School of Engineering, Griffith University, Gold Coast Campus, Queensland 4222, Australia; ${ }^{b}$ Smart Water Research \\ Centre and School of Engineering, Griffith University, Gold Coast Campus, Queensland 4222, Australia
}

\section{Corresponding author:}

Associate Professor Rodney Stewart

Griffith School of Engineering, Gold Coast Campus, Griffith University, Parklands Drive, Southport, QLD 4222

Australia;

Phone: $\quad+61755528778$

Email: r.stewart@griffith.edu.au

\section{Highlights:}

- Energy efficiency rebate schemes should consider site-specific characteristics

- Off-peak electricity tariffs for ASHPWH should have $<5$ hrs of power interruption

- Restrain from excessive reductions in the storage tank set-point temperature

- Oversized ASHPWH have a heightened energy intensity

- Both COP and Heating Capacity influences the performance of ASHPWH

\begin{abstract}
Heat pump water heaters have been increasingly used to promote energy savings in residential buildings. Nonetheless, their performance may vary significantly due to different site-specific characteristics and technical specifications. To examine this issue, this research study sought to identify key performance parameters for air source heat pump water heaters (ASHPWH) in residential buildings in Australia by using a sensitivity analysis through theoretical models calibrated with empirical measurements. ASHPWH were analysed taking into account their energy performance (i.e. annual energy consumption and energy intensity) and level of service (i.e. compliance with recommended hot water temperatures). The assessment encompassed sensitivity analyses for key parameters related to the technical specification of ASHPWH (i.e. coefficients of performance, water heating capacities, hot water storage tank insulation, size and set-point temperature) and site-specific characteristics (i.e. weather conditions, cold water supply temperatures, hot water set-point temperatures and consumption patterns, and the time-distribution of energy according to the electricity tariffs). The findings indicate that the energy performance and the level of service of ASHPWH are mostly influenced by their coefficient of performance and site-specific electricity tariff, respectively. Therefore, careful consideration of ASHPWH technical specifications based on site-specific characteristics should underpin any framework for energy efficiency programmes.
\end{abstract}

Keywords: water heater, heat pump, residential buildings, energy intensity, sensitivity analysis. 


\section{Introduction}

The residential sector accounts for approximately $19-50 \%$ of the total energy consumption of countries worldwide [1], from which there is a considerable potential for energy savings [2]. Despite the implementation of energy efficient appliances and a smaller dwelling size in new residential developments, the contribution of the residential sector to the total energy consumption of nations is likely to increase as a result of its expansion [3]. In residential buildings, hot water supply is among the largest energy end uses [4], corresponding to $18 \%$ in the USA [5], 20\% in Brazil [6], 25\% the UK [3], 26\% in Spain [7] and 30\% in Australia [8]. Hence, there has been an increasing effort to enhance the energy efficiency of domestic hot water supply systems, as the energy saving potential of an energy end use is proportional to its level of energy efficiency, as well as its contribution to the total energy consumption of buildings.

In this context, heat pump water heaters have been increasingly used to promote energy savings in residential buildings $[2,5,9,10]$. Such heaters operate by transferring heat from a colder environment (e.g. air, ground, water, etc.) to a warmer one (e.g. hot water storage tank) through a refrigeration cycle [11]. Among the various types of heat pumps for water heating, air source heat pumps water heaters (ASHPWH) are the most popular due to their lower implementation cost [5]. For ASHPWH, the heat transfer process is simplified by using air circulated by a fan, whereas other systems employ more complex processes (e.g. pipes, pumps, etc.) to source energy. On the other hand, ASHPWH undergo a considerable reduction in their coefficient of performance under cold weather conditions (air source $<5^{\circ} \mathrm{C}$ ) [3]. Therefore, the performance of such systems is generally better in warmer climates.

Financial incentives for renewable energy and energy efficient technologies have helped to facilitate the uptake of heat pump water heaters and other energy efficient initiatives in the residential sector. Since the 2000s, such incentives have been offered by several governments across the globe to achieve national carbon reduction targets implemented after ratification of the Kyoto Protocol. For instance, in Australia, federal and state rebate programs have been offered for the replacement of existing domestic electric water heaters by energy efficient ones (i.e. heat pump and solar water heaters) since 2008 [12]. However, short-term economic objectives may affect the continuation of such policies. This, in turn, may lead to a reduction in the uptake rate of energy efficient technologies by the residential sector as a result of a more thoughtful selection of such technologies by consumers, based on the associated short- to medium-term energy saving potential and associated financial benefit.

The performance of heat pump water heaters may vary significantly due to different site-specific characteristics (e.g. operation patterns, air and cold water temperature, hot water set-point, etc.). Therefore, these systems have to be carefully selected to achieve intended energy savings. Acceptable levels of efficiency for domestic heat pump water heaters ought to be at least twice that of standard electric water heaters in order to attain economic benefits [11]. Moreover, heat pumps must be able to maintain the water in hot water storage tanks at over $55^{\circ} \mathrm{C}$ to prevent the growth of bacteria causing Legionnaires' disease, which may not be achievable when using ASHPWH under certain conditions [3].

The understanding of the energy performance of heat pump water heaters under different weather and operation conditions is essential for supporting both decision makers in scrutinising the benefits of rebate programs for heat pumps, and consumers in determining the economic feasibility of such systems under site-specific conditions. Therefore, reliable tools to predict the performance of heat pumps are required in order to prevent the installation of either oversized or undersized systems in residential buildings [3]. This issue is particularly relevant in Australia, where energy efficiency policies for the residential sector must take into account a vast number of climate conditions due to the continental proportions of the country. Thus, a thorough analysis of the most suitable heat pump type to achieve economic and energy efficient objectives for each region is required taking into account site-specific conditions.

So as to clarify the advantages and disadvantages of heap pump water heaters, several studies addressing their performance were developed in the last two decades [13-21]; however, few of them address the performance of 
ASHPWH under site-specific conditions [22]. Piechowski [23] provided a validation and sensitivity analysis considering different boundary conditions for a heat and mass transfer model employed to estimate the performance of ground source heap pumps (GSHP) under Australian site conditions. The study contributed to understand the significant influence of site-specific conditions (e.g. type and moisture of soils) on the performance GSHP. Johnson [10] undertook a sensitivity analysis of ASHPWH employing a Life Cycle Assessment framework under conditions for residences in the UK; the author concluded that both $80 \%$ of the carbon footprint is energy-related, and site-specific conditions (e.g. leakage rates, property size) may promote variations up to $13 \%$ in the energy demand of domestic ASHPWH. Jenkins et al. [24] studied the energy and carbon performance of ASHPWH taking into account different characteristics of office buildings in the UK, and found that ASHPWH are less carbon intensive than gas water heaters. Vieira et al. [25] analysed the energy and service performance of domestic water heating systems (i.e. ASHPWH, solar and electric) in Brisbane, Australia, and showed that different electricity tariffs and washing machine types may influence the performance of domestic ASHPWH.

To the best of the knowledge of the authors of this study, there still is a paucity of studies to address the knowledge gap existent in regards to the performance of ASHPWH under site-specific conditions for most of the cities in Australia. Such information is crucial to underpin energy-efficiency initiatives in households across the country, as ASHPWH is of crucial importance for the energy-efficiency and carbon agenda of the Australian government [26]. The objective of this study is to identify key performance parameters for ASHPWH in residential buildings in Australia by using a sensitivity analysis through theoretical models calibrated with empirical measurements. This study helps to narrow the knowledge gap about ASHPWH by providing a novel sensitivity analysis for ASHPWH under site-specific conditions at a nationwide scale for Australia.

\section{Method}

\subsection{Overview}

In this study, ASHPWH were analysed taking into account their energy performance (i.e. annual energy consumption and energy intensity) and level of service (i.e. compliance with recommended hot water temperatures). The analysis included several scenarios in order to explore a wide range of ASHPWH configurations (i.e. different coefficients of performance (COP), water heating capacities and hot water storage tank insulation, size and set-point temperature) under different site-specific conditions across Australia (i.e. different weather conditions, cold water supply temperatures, hot water set-point temperatures and consumption pattern, and time-distribution of energy according to the electricity tariff). A summary of the method is illustrated in Fig. 1.

The performance of ASHPWH was determined through laboratory experiments (i.e. empirical analysis) and simulations (i.e. theoretical analysis). The empirical analysis aimed to determine the real operational performance of one of the assessed systems under a specific condition, which has provided detailed information for the calibration of the theoretical analysis. This, in turn, has enabled the assessment of a myriad of scenarios through a sensitivity analysis of key performance parameters (i.e. site-specific characteristics and ASHPWH technical specifications). For each scenario, a performance analysis was carried out in order to determine the level of service and the energy efficiency of ASHPWH. The following sections describe in detail the method employed herein. 


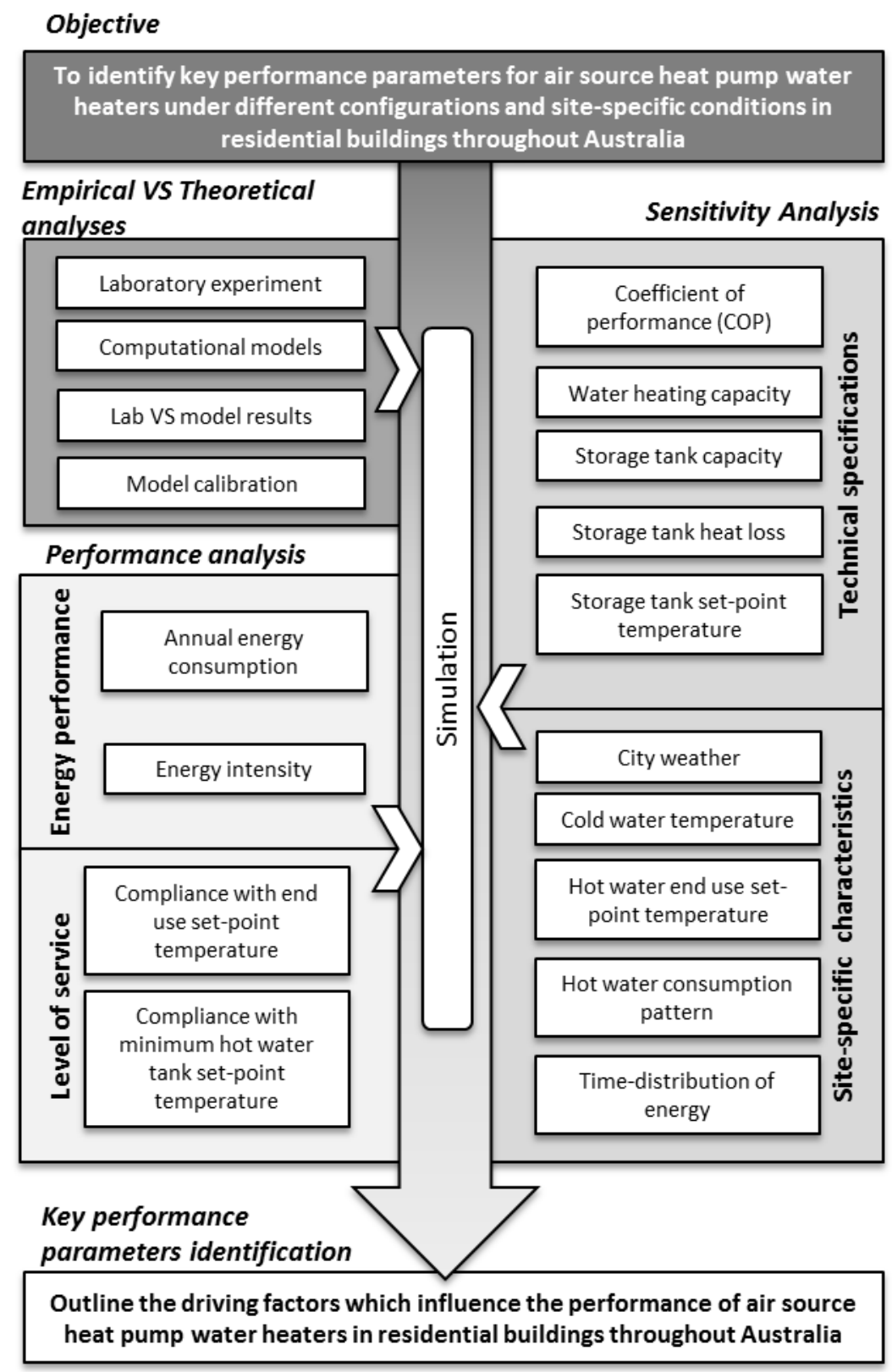

Fig. 1. Flowchart of the study method.

\subsection{Empirical versus theoretical analyses}

\subsubsection{Laboratory experiment}

A laboratory experiment was conducted to determine the performance of a real ASHPWH, from which empirical data was generated to calibrate theoretical computational models. The technical specifications provided by the manufacturer of the studied system are shown in Table 1. 


\section{Table 1}

Technical specifications of the ASHPWH analysed in the laboratory experiment.

\begin{tabular}{lr}
\hline Parameter & Value \\
\hline Refrigerant gas & R417 \\
Rated water heating capacity (W) & 3600 \\
Input power (W) & 900 \\
Maximum input power (W) & 1200 \\
Input current (A) & 4.0 \\
Maximum input current (A) & 5.5 \\
Voltage (V) & $220-240$ \\
Highest water temperature ( $\left.{ }^{\circ} \mathrm{C}\right)$ & 60 \\
Nominal storage capacity (l) & 80 \\
\hline
\end{tabular}

The studied ASHPWH was installed at an outdoor area adjacent to the south-oriented façade of the School of Engineering Laboratory at Griffith University, Gold Coast campus (coordinates: 2757'49.36"S; 153²2'58.07"E). The selected area was also protected by an external building sunshade and adjacent walls (Fig. 2). These characteristics prevented excessive heat transfer by irradiation and convection between the outdoor surroundings and the hot water storage tank surface. Therefore, the majority of the heat transfer was considered to occur via conduction processes through the hot water tank wall.

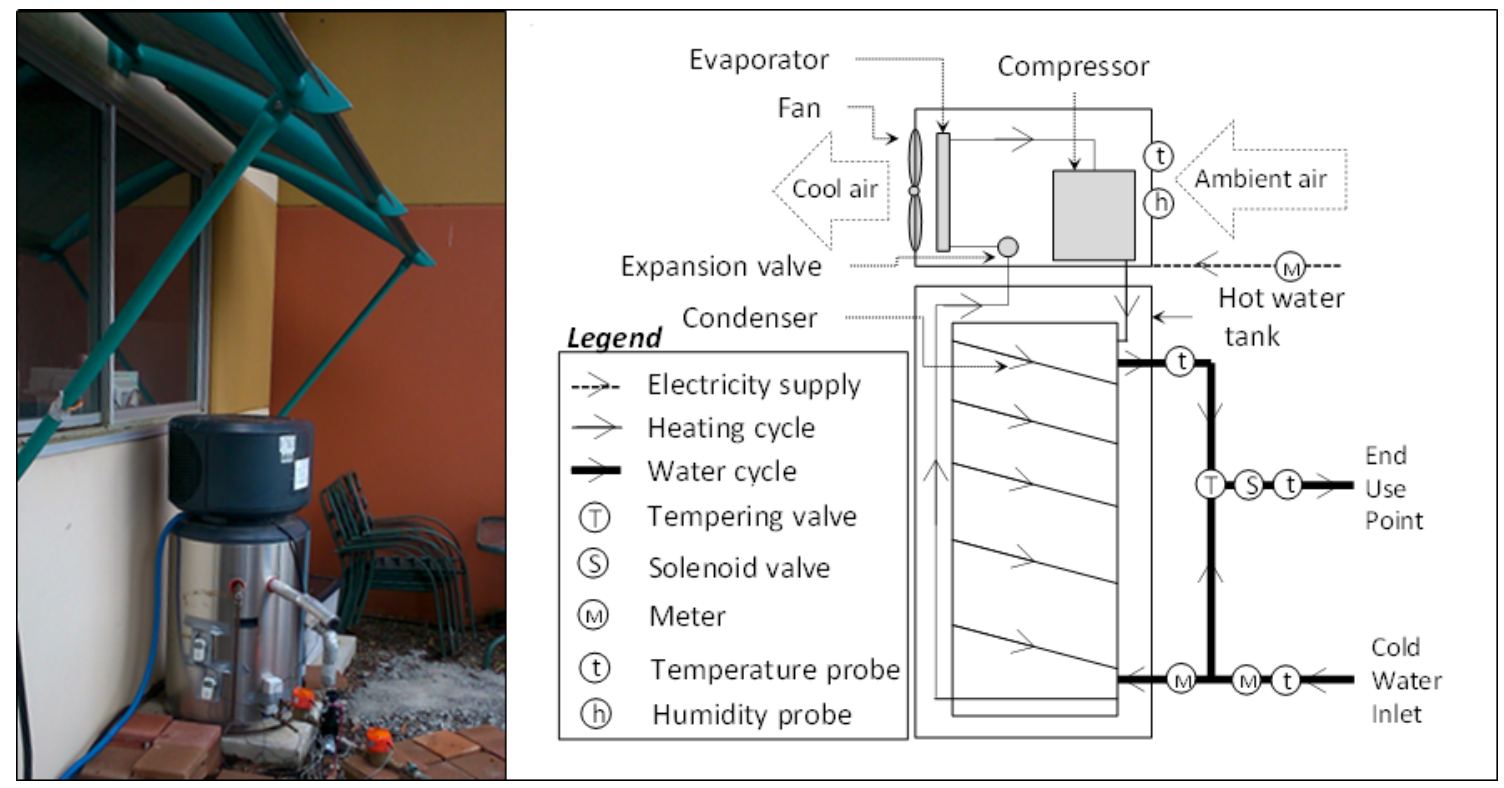

Fig. 2. ASHPWH laboratory experiment.

The thermal resistance and heat loss coefficient related to conduction processes per unit area in hot water tanks were calculated considering one-dimensional heat transfer perpendicular to the surface using Eq. 1.

$$
R=\frac{1}{H_{L}}=\frac{L}{k \cdot A}
$$


Where $\boldsymbol{R}$ is the thermal resistance $(\mathrm{K} / \mathrm{W}) ; \boldsymbol{H}_{\boldsymbol{L}}$ is the heat loss coefficient $(\mathrm{W} / \mathrm{K}) ; \boldsymbol{L}$ is the thickness of the insulation material (m); $\boldsymbol{k}$ is the thermal conductivity of the insulation material $(\mathrm{W} / \mathrm{m} \cdot \mathrm{K})$; and $\boldsymbol{A}$ is the surface area considered per unit area $-1\left(\mathrm{~m}^{2}\right)$.

The temperature of the water at the end use point and the tank inlet and outlet, as well as the outdoor air temperature and humidity at the ASHPWH evaporator air inlet (Fig. 2), were monitored using temperature and humidity data loggers $R C-4$ Elitech set to a 1.5 minute logging interval. This equipment has a precision of one decimal place for temperature and humidity measurements.

The water consumption pattern was emulated using a solenoid valve connected to a timer, which was set to open at 6:35 am, 5:35 pm and 7:35 pm in order to represent hot water consumption events at peak hours as described by Vieira et al. [25]. Each water consumption event had duration of three minutes and an average water consumption volume equal to 50 l. By adjusting the tempering valve (i.e. valve utilised to mix hot and cold water in order to prevent scalding at end use points), the water temperature at the consumption point (i.e. solenoid valve) was set to $42{ }^{\circ} \mathrm{C}$. This temperature is within the range described in the literature for the set-point temperatures of end use points in residential buildings (see section 3.2.1).

The energy and water consumption of the ASHPWH were monitored using high resolution energy and water meters with $0.1 \mathrm{~W} /$ pulse and $0.0083 \mathrm{l} /$ pulse precision, respectively. Data loggers were set to record pulses every five seconds. The collected water and energy data was converted into diurnal demand consumption patterns with a temporal resolution of one minute by using an electronic spreadsheet.

\subsubsection{Computational models}

Computational models were utilised to generate theoretical data. Such models were developed using the software EnergyPlus 8.1, which is provided by the United States Department of Energy (US-DOE), and is used for energy performance analysis in buildings [1,25,27-30]. The equations and concepts employed to calculate heat transfer processes in models developed in EnergyPlus (e.g. ASHPWH models) follow fundamental heat and mass transfer processes and are detailed by US-DOE [31]. These equations and concepts are also vastly discussed by Incropera et al. [32].

In EnergyPlus, models for water heating systems are based on fluid ('plant') loop calculations with mass continuity and heat exchange between components and heat exchangers (e.g. evaporator of ASHPWH), whereby a supply side and a demand side are stablished. Furthermore, the models developed in EnergyPlus are formed by several objects (Table 2) utilised to specify the technical specifications of water heating systems as well as site-specific characteristics. Based on the structure required in the software, the herein models for ASHPWH were developed as illustrated in Fig. 3.

The loop structure of the models is formed by three branches in each side (i.e. supply and demand sides). In the supply side, the first branch contains a variable speed pump, which is an compulsory object in EnergyPlus plant loop models; however, its energy consumption was disregarded from results, as almost always hot water supply systems are connected to town water supply in Australia, and hence do not require on-site pumping. The second branch in the supply side represents the ASHPWH, and is formed by three objects, namely: hot water tank, air source heat pump, and direct expansion (DX) coil (evaporator). Through the combination of these three objects, the technical specifications of assessed ASHPWH were assigned (e.g. inlet air source (outdoor air), hot water tank volume, etc.). The last branch of the supply side was composed by an adiabatic pipe, for which heat losses are disregarded as such losses were taking into account only for hot water tanks and their immediate pipe connections (tank inlet and outlet). In the demand side, the 
first and the last branches were also composed of adiabatic pipes; whereas, the middle one was formed by objects which simulate the water consumption pattern and set-point temperature of end use points. With this model structure, a myriad of configurations for ASHPWH could be assessed in this paper (e.g. 396 scenarios in the sensitivity analysis). In Table 2, all the objects employed into the computational models are described.

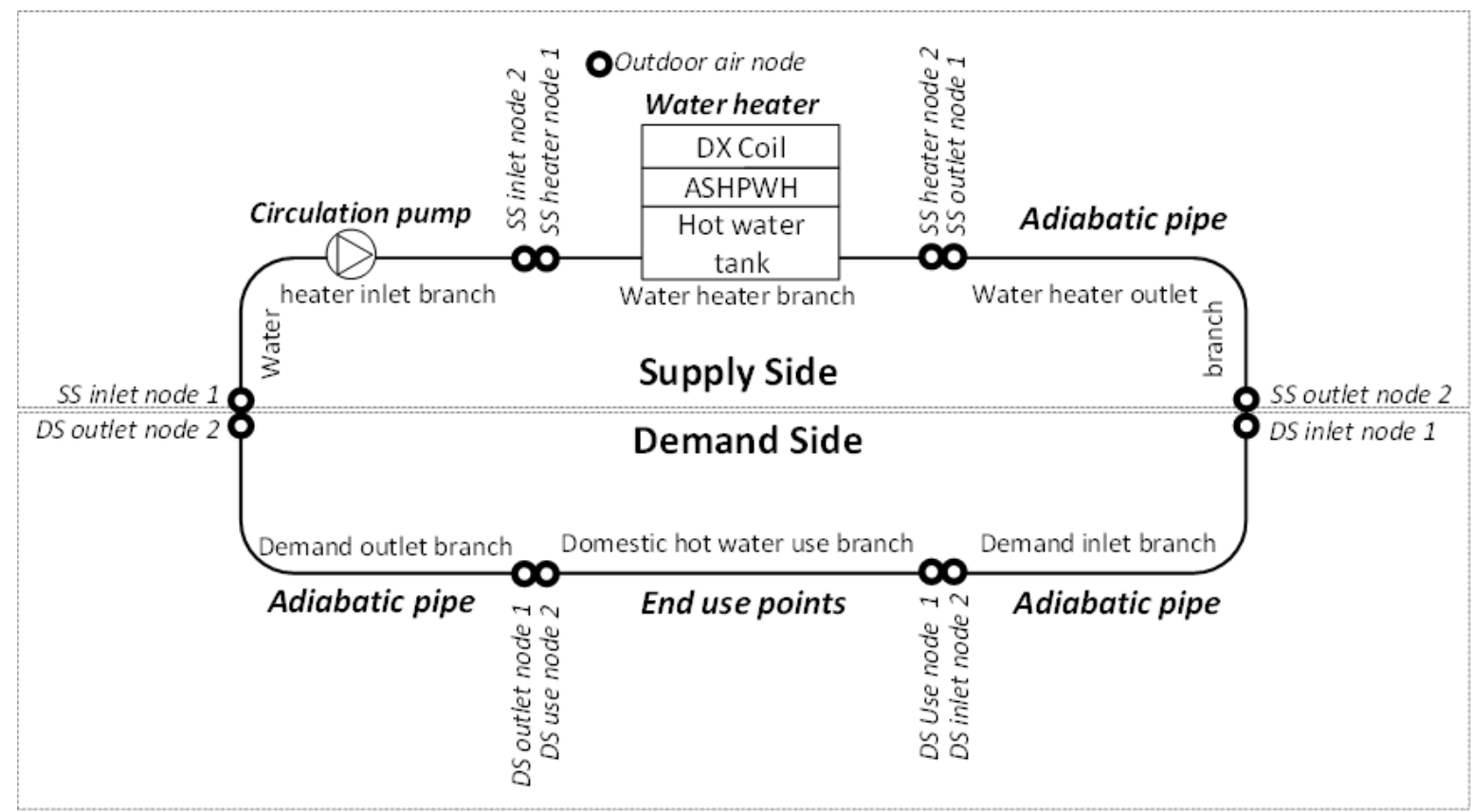

Fig. 3. Computational model structure.

Table 2

Objects of computational models.

\begin{tabular}{|c|c|c|c|}
\hline Model Object & Description & Configuration* & Selection for models \\
\hline Version & $\begin{array}{l}\text { Identifies the version of the } \\
\text { EnergyPlus file (IDF file). }\end{array}$ & Fixed & 8.1 \\
\hline $\begin{array}{l}\text { Simulation } \\
\text { control }\end{array}$ & $\begin{array}{l}\text { Specifies the type of calculations of } \\
\text { the simulation. }\end{array}$ & Fixed & Run simulation for weather file run periods. \\
\hline Building & $\begin{array}{l}\text { Describes parameters for the } \\
\text { simulation of the building. }\end{array}$ & Fixed & Suburbs - models for residential area (suburbia). \\
\hline Time step & $\begin{array}{l}\text { Determines the number of time steps } \\
\text { within an hour for simulations. }\end{array}$ & Fixed & 60 time steps per hour (i.e. 1 minute time step). \\
\hline Site location & Specifies the building location. & Variable & $\begin{array}{l}\text { Different cities in Australia. This information also } \\
\text { relates to the weather file of each city. }\end{array}$ \\
\hline Run period & $\begin{array}{l}\text { Defines the time period used for } \\
\text { simulations. }\end{array}$ & Variable & $\begin{array}{l}\text { All year around for different scenarios. Same } \\
\text { period than empirical data for model calibration } \\
\text { (24-30 June 2014). }\end{array}$ \\
\hline $\begin{array}{l}\text { Site: water } \\
\text { mains } \\
\text { temperature }\end{array}$ & $\begin{array}{l}\text { Determines the temperature of water } \\
\text { supplied by underground water } \\
\text { mains. }\end{array}$ & Variable & $\begin{array}{l}\text { Correlation as per Hendron et al. [33] for different } \\
\text { scenarios. Same than empirical data for model } \\
\text { calibration. }\end{array}$ \\
\hline $\begin{array}{l}\text { Schedule type } \\
\text { limits }\end{array}$ & $\begin{array}{l}\text { Indicates the types of values used } \\
\text { into simulation schedules. }\end{array}$ & Fixed & 'Any number' and 'Fraction'. \\
\hline $\begin{array}{l}\text { Schedule: } \\
\text { compact }\end{array}$ & $\begin{array}{l}\text { Defines in detail schedules utilised } \\
\text { for simulations. }\end{array}$ & Variable & $\begin{array}{l}\text { E.g., End-use point temperature, hot water } \\
\text { temperature set-point, water consumption patterns, }\end{array}$ \\
\hline
\end{tabular}




\begin{tabular}{|c|c|c|c|}
\hline Model Object & Description & Configuration* & Selection for models \\
\hline & & & etc. \\
\hline Schedule: file & $\begin{array}{l}\text { Utilises schedules obtained from } \\
\text { data monitoring. }\end{array}$ & Variable & $\begin{array}{l}\text { Cold water temperature from laboratory } \\
\text { experiment. }\end{array}$ \\
\hline $\begin{array}{l}\text { Global } \\
\text { geometry rules }\end{array}$ & $\begin{array}{l}\text { Describes the geometric parameters } \\
\text { used for simulations. }\end{array}$ & Fixed & $\begin{array}{l}\text { Start vertex position: Upper left corners; Vertex } \\
\text { entry direction: Counter-clockwise; Coordinate } \\
\text { system: Relative. }\end{array}$ \\
\hline Sizing: plant & $\begin{array}{l}\text { Defines the type of plant loop and } \\
\text { associate flow rates calculations. }\end{array}$ & Fixed & Loop type: Heating. \\
\hline Fan: OnOff & $\begin{array}{l}\text { Models constant air volume fans } \\
\text { operating on an on-off cycle. }\end{array}$ & Fixed & $\begin{array}{l}\text { Heat pump fan technical specifications: } 0.7 \text { total } \\
\text { efficiency, } 100 \text { Pa pressure rise, } 2.7 \text { maximum flor } \\
\text { rate, and } 90 \% \text { motor efficiency. }\end{array}$ \\
\hline $\begin{array}{l}\text { Coil: water } \\
\text { heating: air to } \\
\text { water heat } \\
\text { pump }\end{array}$ & $\begin{array}{l}\text { Models the direct expansion 'coil' } \\
\text { (ASHPWH evaporator). }\end{array}$ & Fixed & $\begin{array}{l}\text { Operate in conjunction with the objects } \\
\text { 'Fan:OnOff', WaterHeater:HeatPump', and } \\
\text { 'WaterHeater:Stratified'. }\end{array}$ \\
\hline Branch & $\begin{array}{l}\text { Assign components for model } \\
\text { schemes at a mid-level (branch } \\
\text { level). For heating loop models, } \\
\text { there are three branches for the } \\
\text { supply side and three for the demand } \\
\text { side. }\end{array}$ & Fixed & $\begin{array}{l}\text { Supply side: water heater inlet (circulation pump), } \\
\text { water heater (heat pump), and water heater outlet } \\
\text { (adiabatic pipe). } \\
\text { Demand side: demand inlet (adiabatic pipe), } \\
\text { domestic hot water use (end use points), and } \\
\text { demand outlet (adiabatic pipe). }\end{array}$ \\
\hline Branch list & $\begin{array}{l}\text { Sorts and groups branches for model } \\
\text { schemes into supply and demand } \\
\text { sides. }\end{array}$ & Fixed & As above \\
\hline $\begin{array}{l}\text { Connector: } \\
\text { splitter }\end{array}$ & $\begin{array}{l}\text { Defines how many and which } \\
\text { branches will follow the first branch } \\
\text { of a side (loop segment). }\end{array}$ & Fixed & $\begin{array}{l}\text { Water heater splitter (Supply side): 'water heater } \\
\text { inlet’ followed by 'water heater'. } \\
\text { Demand splitter (Demand side): ‘demand inlet' } \\
\text { followed by 'domestic hot water use'. }\end{array}$ \\
\hline $\begin{array}{l}\text { Connector: } \\
\text { mixer }\end{array}$ & $\begin{array}{l}\text { Defines how many and which } \\
\text { branches will precede the last branch } \\
\text { of a side. }\end{array}$ & Fixed & $\begin{array}{l}\text { Water heater mixer (Supply side): 'water heater } \\
\text { outlet' preceded by 'water heater'. } \\
\text { Demand mixer (Demand side): 'demand outlet' } \\
\text { preceded by 'domestic hot water use’. }\end{array}$ \\
\hline Connector list & $\begin{array}{l}\text { Joins connector devices (splitters } \\
\text { and mixers). }\end{array}$ & Fixed & $\begin{array}{l}\text { Water heater connectors (Supply side): 'Water } \\
\text { heater splitter' followed by 'Water heater mixer'. } \\
\text { Demand connector (Demand side): 'Demand } \\
\text { splitter' followed by 'Demand mixer'. }\end{array}$ \\
\hline $\begin{array}{l}\text { Outdoor air } \\
\text { node }\end{array}$ & $\begin{array}{l}\text { Defines outdoor air conditions based } \\
\text { on the weather file. }\end{array}$ & Variable & $\begin{array}{l}\text { Weather files from Representative Meteorological } \\
\text { Year (RMY) for different cities, and empirical data } \\
\text { for model calibration. }\end{array}$ \\
\hline Pipe: adiabatic & Represents pipes to connect & Fixed & As per ‘Branch’ object description. \\
\hline
\end{tabular}

considered for this type of pipe. $\begin{array}{ll}\text { speed } & \text { Represents the circulation system in } \\ \text { the model. The 'pump' object is an }\end{array}$ essential item of plant loop models (e.g. hot water use loop) in EnergyPlus.

Water heater: stratified

Water heater: heat pump
Defines the characteristics of hot water tanks (e.g. volume, number of stratification layers, position (vertical or horizontal), electric heating element characteristics, heating loss coefficients)

Defines the characteristics of the ASHPWH (e.g. hot water tank object, coil object, fan object).
Fixed

Variable

Variable

The flow rate and power rate were auto-sized by the software. Energy consumption from pumps was disregarded from results as hot water supply systems are almost always supplied by pressurised town water supply in Australia.

The volume of the tank and heating loss coefficients were considered variable. Auxiliary electric heating elements were not considered. Six stratification layers in hot water tanks were considered.

The system was selected to work at outdoor conditions. Technical specification variations were associated with related objects. 


\begin{tabular}{|c|c|c|c|}
\hline Model Object & Description & Configuration* & Selection for models \\
\hline Plant loop & $\begin{array}{l}\text { Determines the characteristics of the } \\
\text { hot water system loop. }\end{array}$ & Fixed & $\begin{array}{l}\text { The flow rate of the system was auto-sized, and } \\
\text { connections/branches defined as per Fig. } 3 .\end{array}$ \\
\hline $\begin{array}{l}\text { Plant } \\
\text { equipment list }\end{array}$ & $\begin{array}{l}\text { Specifies available plant loop } \\
\text { equipment for loop operation } \\
\text { schemes. }\end{array}$ & Fixed & $\begin{array}{l}\text { The 'WaterHeater:HeatPump’ object was specified } \\
\text { for the hot water system loop. }\end{array}$ \\
\hline $\begin{array}{l}\text { Plant } \\
\text { equipment } \\
\text { operation: } \\
\text { heating load }\end{array}$ & $\begin{array}{l}\text { Determines the load limits in Watt } \\
\text { for an equipment list. }\end{array}$ & Fixed & $\begin{array}{l}\text { The load was not limited, letting the domestic } \\
\text { ASHPWH operate within required loads depending } \\
\text { on technical specifications. Therefore, the limit } \\
\text { range was } 0-10,000,000 \mathrm{~W} \text {. }\end{array}$ \\
\hline $\begin{array}{l}\text { Plant } \\
\text { equipment } \\
\text { operation } \\
\text { scheme }\end{array}$ & $\begin{array}{l}\text { Controls the conditions in which the } \\
\text { hot water system loop is available. }\end{array}$ & Fixed & Always on. \\
\hline $\begin{array}{l}\text { Setpoint } \\
\text { manager } \\
\text { scheduled }\end{array}$ & $\begin{array}{l}\text { Sets the temperature required at } \\
\text { nodes of the hot water system loop. }\end{array}$ & Variable & $\begin{array}{l}\text { Set the temperature at the node 'SS outlet node 2' } \\
\text { (Fig. 3) to different temperatures depending on the } \\
\text { assessed end use set-point temperature target. }\end{array}$ \\
\hline $\begin{array}{l}\text { Water use: } \\
\text { equipment }\end{array}$ & $\begin{array}{l}\text { Simulates water end uses } \\
\text { consumption and temperature. }\end{array}$ & Variable & $\begin{array}{l}\text { Different water consumption patterns and end use } \\
\text { set-point temperatures were defined depending on } \\
\text { the assessed scenario. }\end{array}$ \\
\hline $\begin{array}{l}\text { Water use: } \\
\text { connections }\end{array}$ & $\begin{array}{l}\text { Lists and connects 'water use: } \\
\text { equipment' objects. }\end{array}$ & Fixed & $\begin{array}{l}\text { Always employed the same 'water use: equipment' } \\
\text { object. }\end{array}$ \\
\hline $\begin{array}{l}\text { Output: } \\
\text { variable }\end{array}$ & $\begin{array}{l}\text { Defines the output variables to be } \\
\text { reported in the model. }\end{array}$ & Fixed & $\begin{array}{l}\text { It was reported the cold, tank, and end use } \\
\text { temperatures, as well as water and energy } \\
\text { consumptions on a time step frequency. }\end{array}$ \\
\hline
\end{tabular}

Note: *The configuration of model objects can be 'fixed' (without variation among models for different scenarios) or 'variable'(with variation among models for different scenarios).

\subsubsection{Laboratory versus model results}

A comparison of empirical and theoretical results for the studied ASHPWH was carried out to determine the accuracy of the developed computational models. In order to perform this analysis, the empirical data was collected as described in Section 2.2.1, while the theoretical data was obtained as explained in Section 2.2.2.

The comparison was performed by developing computational models to represent the empirical data generated in the laboratory experiment considering a one minute time step. The input data of the models comprised of the data described in Table 2 and Table 3.

Based on rated water heating capacity and input powers described in the technical specification of the studied system (Table 1), the COP of the ASHPWH was calculated as follows:

$$
C O P=\frac{H C}{P}
$$

where $\boldsymbol{C O P}$ is the coefficient of performance (W/W); $\boldsymbol{H C}$ is the water heating capacity (W); and $\boldsymbol{P}$ is the input electric power (W).

The comparison between models to represent empirical results (theoretical data) and actual laboratory results was performed by examining the different between the input power consumption obtained from measured and modelled 
results for the ASHPWH. This parameter was selected as the key parameter for this comparison as it is dependent on all the other parameters related to the ASHPWH operation, including but not restricted to: COP, water heating capacity, heat losses, water consumption pattern, end use temperature set-point, lower and upper hot water storage tank temperature thresholds, inlet cold water temperature, inlet outdoor air temperature and humidity. The input power consumption was directly measured in the experiment or generated as an output of models.

The level of accuracy of theoretical results in relation to empirical results was determined via statistical correlations. For this purpose, the energy consumption of the ASHPWH was analysed on a minute basis over the course of one week during winter: 24-30 June 2014. This analysis was performed on a one minute basis for non-zero values (i.e. values located out of the origin of either the ' $y$ ' or the ' $x$ ' axis).

\section{Table 3}

Input parameters of computational models.

\begin{tabular}{|c|c|c|c|}
\hline Parameter & Unit & Value & Source \\
\hline Air temperature and humidity & ${ }^{\circ} \mathrm{C}$ & Oscillating & Empirical data \\
\hline Cold water temperature & ${ }^{\circ} \mathrm{C}$ & Oscillating & Empirical data \\
\hline End use temperature set-point & ${ }^{\circ} \mathrm{C}$ & 42 & Empirical data \\
\hline $\begin{array}{l}\text { Lower and upper hot water } \\
\text { tank temperature thresholds }\end{array}$ & ${ }^{\circ} \mathrm{C}$ & $50-60$ & $\begin{array}{l}\text { Technical specification of the } \\
\text { ASHPWH }\end{array}$ \\
\hline $\begin{array}{l}\text { Storage tank heat loss } \\
\text { coefficient }\end{array}$ & $\mathrm{W} / \mathrm{K}$ & $\begin{array}{l}1(38 \mathrm{~mm} \text { insulation }-0.04 \\
\mathrm{W} / \mathrm{m} \cdot \mathrm{K})\end{array}$ & $\begin{array}{l}\text { Technical specification of the } \\
\text { ASHPWH }\end{array}$ \\
\hline $\begin{array}{l}\text { Pipe work heat loss coefficient } \\
\text { during hot water supply }\end{array}$ & - & Disregarded & - \\
\hline Water consumption pattern & l/day & $\begin{array}{l}\text { 150 l/day in three events of } 50 \\
\text { l/event at 6:35 am, 5:35 pm and } \\
\text { 7:35 pm. }\end{array}$ & Empirical data \\
\hline Rated water heating capacity & $\mathrm{W}$ & 3600 & $\begin{array}{l}\text { Technical specification of the } \\
\text { ASHPWH }\end{array}$ \\
\hline
\end{tabular}

\subsubsection{Model calibration}

The calibration of computational models was performed by adjusting the input parameters of the simulated ASHPWH based on the empirical results. Such calibration was also performed by means of statistical correlations in order to define the most accurate fit between theoretical and empirical results for energy consumption. Statistical analyses were carried out on a one minute basis. Therefore, the higher the coefficient of determination $\left(\mathrm{R}^{2}\right)$ between empirical and theoretical results, the more accurate the model was considered.

The adjusted input parameters used in the computational models included COP, heating capacity, storage tank capacity and heat loss coefficient, which were adjusted using their respective objects described in Tables 3 . The percentage differences between simulation input parameter values before and after the calibration (i.e. non-calibrated and calibrated results) for the assessed ASHPWH were also applied to calibrate the simulations performed for the scenarios assessed in the sensitivity analysis. Thus, the technical specifications of ASHPWH, including their COP, heating capacity, storage tank capacity and heat loss coefficient, were calibrated considering the same proportional difference between non-calibrated and calibrated simulations for models used to represent the empirical results from the laboratory experiment. 


\subsection{Sensitivity analysis}

The influence of input parameters on the output results was assessed through sensitivity analyses for a range of input parameter values. Two categories of input parameters were analysed in the sensitivity analysis: (i) technical specifications of ASHPWH; and (ii) site-specific characteristics. For each input parameter, the variability of their values was determined using statistical analyses or ranges described in the literature. Moreover, the nationwide climate conditions were also assessed. In the following sections, the method utilised to determine each input parameter and their respective values is described in detail.

\subsubsection{Variability of technical specifications}

The technical specification category relates to parameters associated with the operation performance of ASHPWH. Under this category, the following parameters were assessed: COP, water heating capacity, storage tank capacity, storage tank heat loss coefficient, and storage tank set-point temperature.

Among the existing ASHPWH available on the market in Australia, only those classified by the Clean Energy Regulator of the Australian Government as part of the Small-scale Renewable Energy Scheme (SRES) (i.e. rebate scheme for residential solar and heat pump water heaters in Australia) were taken into account in the present study ( $n=173)$. From this sample, the aforementioned parameters, except for the heat loss coefficient of hot water tanks, were determined for each system through a desktop review, with information sourced from ASHPWH manufacturers and retailers websites.

Due to the scarcity of data provided by manufacturers with regards to the insulation characteristics of storage tanks, their heat loss coefficient was determined through a literature review of scientific papers. Omer et al. [33] and Li et al. [34] have described insulation materials $(\sim 0.04 \mathrm{~W} / \mathrm{m} \cdot \mathrm{K})$ and thicknesses $(\sim 38 \mathrm{~mm})$ that give rise to a heat loss coefficient of approximately $1 \mathrm{~W} / \mathrm{K}$ for 300 and $150 \mathrm{l}$ hot water tanks, respectively. This heat loss coefficient is comparable to the technical specification of the system assessed in the empirical analysis. In order to determine the potential for improvements in the insulation of hot water tanks, the same insulation thickness was used to assess the thermal resistance of insulation materials with different thermal conductivity coefficients $(\mathrm{W} / \mathrm{m} \cdot \mathrm{K})$ described by Omer et al. [33], including: glass fibre (0.037), polystyrene (0.030), polyurethane (0.025), polyisocyanurate (0.021), and vacuum insulation panel (0.010).

\subsubsection{Variability of site-specific characteristics}

The site characteristics category encompassed all the input parameters which range on a site-specific basis used to describe the exchange of energy and water flows between ASHPWH and the surroundings. This category was analysed into the sensitivity analysis by including the following parameters: cold water temperature, hot water set-point temperature, hot water consumption pattern, and time-distribution of energy according to electricity tariff.

The cold water temperature (i.e. inlet water temperature supplied to ASHPWH) was estimated by using the method described by Hendron et al. [35]. This method utilises the annual average outdoor air temperature (dry-bulb) and the maximum difference in the monthly average outdoor air temperature, which were calculated from the Representative Meteorological Year (RMY) climate files. Moreover, variations in temperature of the cold water supply due to factors other than outdoor air temperature (e.g. water mains depth, water table levels, incidence of solar radiation on covering ground surface, and soil type and associated thermal capacity) were also taken into account. Such variations were assumed to be equal to a temperature oscillation of $8{ }^{\circ} \mathrm{C}$ within a single water supply zone described by Kenway et al. [36] for Melbourne.

A representative hot water consumption pattern range for Australian households was estimated taking into account the national per capita hot water demand and household (hh) size. For this purpose, the following data were used: (i) the 
upper and lower daily hot water demand prescribed by the Plumbing Reference Guide of Australia [37] (i.e. 50 and 70 l/p/day); and (ii) the average household size in Australia (2-3 p/hh [38]). Taking into account both pieces of information, the estimated total water consumption ranged from 100 to 210 l/hh/day. Diurnal hot water consumption patterns were estimated based on both the estimated total hot water consumption pattern range, and the residential hot water consumption peak hours from 7 am to 9 am and from 5 pm to 7 pm, as described by Vieira et al. [25] for Brisbane.

The end use hot water set-point temperature adopted in this study was $40{ }^{\circ} \mathrm{C}$ on average, ranging from 35 to $50{ }^{\circ} \mathrm{C}$. Similar assumptions are described elsewhere $[35,39,40]$. The adopted temperature set-point for hot water storage tanks was based on the review of ASHPWH specifications.

The time-distribution of energy according to electricity tariff was defined through a literature review of energy tariff schemes adopted by electricity distributors in Australia. In total, the tariffs provided by 13 electricity distributors across all states and territories, expect for the Northern Territory, were assessed.

\subsubsection{Energy performance classes of stochastic input parameters}

The variability of values related to each input parameter of the two assessed categories (i.e. technical specifications and variable site conditions) which may vary randomly were analysed considering different probabilities of occurrence, namely: lower-extreme, lower-standard, standard, upper-standard, and upper-extreme. Such categories were defined for the input parameters as described in Table 4.

\section{Table 4}

Stochastic variability of input parameter values for sensitivity analyses in relation to energy performance classes.

\begin{tabular}{|c|c|c|}
\hline $\begin{array}{l}\text { Energy } \\
\text { performance } \\
\text { class }\end{array}$ & Description & Statistical correspondence \\
\hline Upper-extreme & $\begin{array}{l}\text { Upper range of values based on an extrapolation of current value ranges } \\
\text { described in the literature/technical specifications. It represents extreme } \\
\text { levels of service, site characteristics or technological advancements which } \\
\text { are not expected, common or currently available, and are likely to have a } \\
\text { beneficial impact on the energy performance of systems. }\end{array}$ & $\begin{array}{l}\text { Extreme value, at a } 99 \% \\
\text { confidence interval, which } \\
\text { promotes an enhancement in the } \\
\text { energy performance. }\end{array}$ \\
\hline Upper-standard & $\begin{array}{l}\text { Upper range of values described in the literature/technical specifications. It } \\
\text { represents the maximum level of performance or the most advantageous } \\
\text { standard value currently achievable which causes a beneficial impact on the } \\
\text { energy performance of systems in comparison with standard values. }\end{array}$ & $\begin{array}{l}\text { Extreme value, at a } 95 \% \\
\text { confidence interval, which } \\
\text { promotes an enhancement in the } \\
\text { energy performance. }\end{array}$ \\
\hline Standard & $\begin{array}{l}\text { Most frequent or recurrent value described in the literature/technical } \\
\text { specifications. It represents the status quo, general assumption or default } \\
\text { value applicable to a parameter. }\end{array}$ & Mean value. \\
\hline Lower-standard & $\begin{array}{l}\text { Lower range of values described in the literature/technical specifications. It } \\
\text { represents the minimum level of performance or the least advantageous } \\
\text { standard value currently required which causes a detrimental impact on the } \\
\text { energy performance of systems in comparison with standard values. }\end{array}$ & $\begin{array}{l}\text { Extreme value, at a } 95 \% \\
\text { confidence interval, which } \\
\text { promotes a reduction in the } \\
\text { energy performance. }\end{array}$ \\
\hline Lower-extreme & $\begin{array}{l}\text { Lower range of values based on an extrapolation of current value ranges } \\
\text { described in the literature/technical specifications. It represents extreme } \\
\text { levels of service, site characteristics or technological limitations which are } \\
\text { not expected, common or foreseen, and are likely to have a detrimental } \\
\text { impact on the energy performance of systems. }\end{array}$ & $\begin{array}{l}\text { Extreme value, at a } 99 \% \\
\text { confidence interval, which } \\
\text { promotes a reduction in the } \\
\text { energy performance. }\end{array}$ \\
\hline
\end{tabular}


Other than for the heat loss coefficient and the time-distribution of energy, the extreme values of input parameters for the sensitivity analysis were estimated using statistical analysis, in which parameter values defined through the literature (see Sections 2.3.1 and 2.3.2) were assumed to be part of a population described by a Gaussian (normal) distribution. The expected value of the distribution (i.e. mean value) for the assessed parameters was assumed to be equal to the defined standard value class for each parameter. The lower-standard and upper-standard value classes were assumed to be the thresholds that encompass 95\% of the values encountered in the population (i.e. 95\% confidence interval). This assumption was based on the nominal confidence interval of 95\% typically practiced in engineering projects as described in other studies (i.e. Moffat [41], Phillips \& Eberhardt [42] and Mathioulakis et al. [43]). The broader level of confidence of $99 \%$ was adopted to predict extreme values (i.e. lower-extreme and upper-extreme values), which were calculated through Eq. 3:

$$
V_{99}=S \pm\left[\frac{z_{99}}{z_{95}} \times\left|V_{95}-S\right|\right]
$$

Where $\boldsymbol{V}_{\boldsymbol{9 9}}$ is the extreme value at a $99 \%$ confidence interval (lower-extreme or upper-extreme values); $\boldsymbol{S}$ is the mean value (standard value); $\boldsymbol{V}_{95}$ is the extreme value at $95 \%$ confidence interval (lower-standard or upper-standard values); $z_{99}$ is the $99 \%$ confidence interval factor from the Gaussian distribution; and $z_{95}$ is the $95 \%$ confidence interval factor from the Gaussian distribution.

Eq. 3 was applied to determine the extreme values of most input parameters, except for the lower-extreme values for storage tanks and end use set-point temperature. The lower-extreme value for storage tank capacities was considered to be equal to the minimum value found in the literature review, for the $99 \%$ confidence interval would lead to extremely low values (<10 l). A similar approach was used to calculate the storage tank set-point temperature, for which the minimum and maximum set-point temperature described by the manufacturers was considered to be equal to the $99 \%$ confidence interval. The temperature analysis for end use points was limited to $50{ }^{\circ} \mathrm{C}$, as it corresponds to the typical minimum temperature of the hot water storage tank of ASHPWH.

\subsubsection{Energy performance classes of non-stochastic input parameters}

The analysis for the heat loss coefficient was carried out considering the use of different insulation materials with a standard $38 \mathrm{~mm}$ thickness and different thermal conductivity values as per Section 2.3.1, varying between 0.26 and 0.98 W/K (Fig. 4).

The energy performance classes adopted to assess the time-distribution of energy according to electricity tariff were different from the classes used to analyse other parameters. For most of the 24 reviewed tariff schemes, hours of the day were classified as 'peak', 'shoulder' or 'off-peak' and the time-distribution of energy was classified as 'controlled tariff' (i.e. electricity distribution with interruption over peak hour periods) and 'night off-peak tariffs' (i.e. electricity distribution over off-peak hours only). Based on the peak hours classification provided by energy distributors for controlled tariffs, three controlled electricity supply tariffs were determined: (i) minimum controlled tariff (TC1), i.e. controlled tariff with the least amount of peak hours of all reviewed controlled tariffs; (ii) average controlled tariff (TC2), i.e. controlled tariff based on the average classification of peak hours among the reviewed controlled tariffs; and (iii) maximum controlled tariff (TC3), i.e. controlled tariff with the most amount of peak hours of all reviewed controlled tariffs. The night off-peak tariff was determined as the energy supply between 10 pm and 7 am, whereas the 
standard tariff was associated with a 24 hours electricity supply without interruption. The derived tariff schemes are summarised in Table 5.

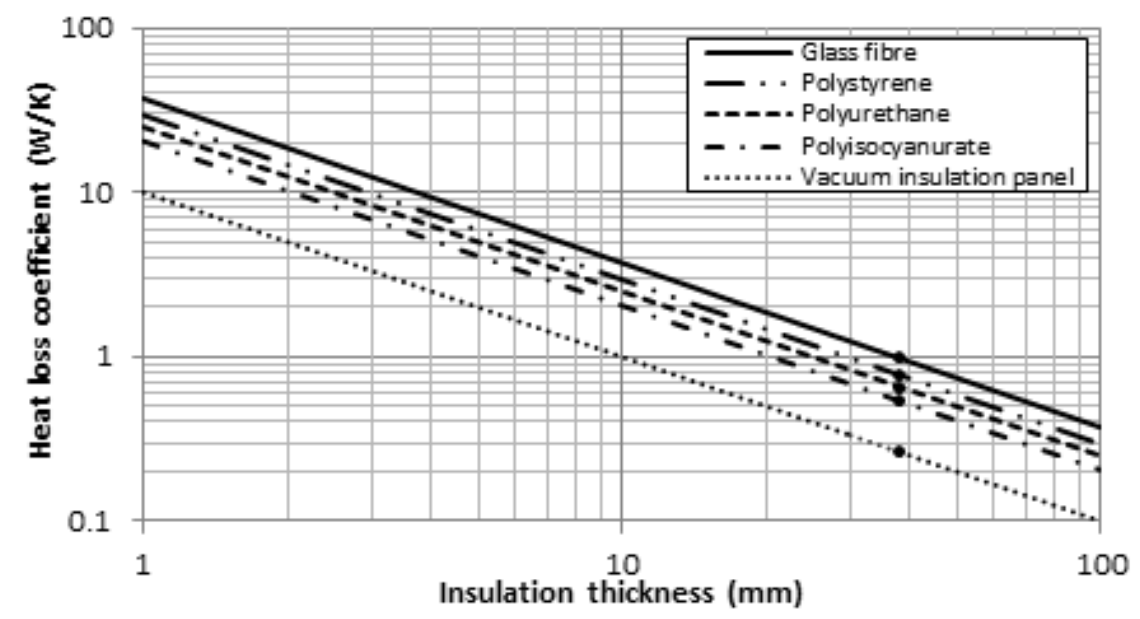

Fig. 4. Heat loss coefficient of different insulation materials and thicknesses.

\section{Table 5}

Input values for the time-distribution of energy according to electricity tariff scheme.

\begin{tabular}{lccc}
\hline Tariff scheme classes & ID & Electricity interruption period & Total hours of electricity interruption \\
\hline Night off-peak & TN & $10 \mathrm{pm}-7 \mathrm{pm}$ & 15 \\
Maximum controlled & TC3 & $7 \mathrm{am}-9 \mathrm{am} / 1 \mathrm{pm}-9 \mathrm{pm}$ & 10 \\
Average controlled & TC2 & $4 \mathrm{pm}-8 \mathrm{pm}$ & 4 \\
Minimum controlled & TC1 & $5 \mathrm{pm}-8 \mathrm{pm}$ & 3 \\
Standard tariff & TS & None & 0 \\
\hline
\end{tabular}

Different climate conditions were assessed by simulations undertaken using RMY climate files downloaded from the EnergyPlus website for a range of cities across Australia, including: one with tropical climate, Zone 1 (Darwin); one with semi-arid climate, Zone 2 (Alice Springs); one with sub-tropical climate, Zone 3 (Brisbane); four with temperate climate, Zone 3 (Adelaide, Perth and Sydney) and Zone 4 (Melbourne); and two with cool temperate climate, Zone 5 (Hobart and Canberra). These zone classifications are part of the SRES, and are used to define national standards and rebate schemes applicable to ASHPWH installed in different regions of Australia.

\subsubsection{Computational models}

The sensitivity analysis was carried out using the determined input parameters to perform computational models in a similar manner as described in Section 2.2.3. The sensitivity analysis was performed varying one factor at a time. Hence, each input parameter was considered separately for each city by varying its values in accordance with the different energy performance classes, while maintaining the other input parameters fixed at the 'standard' class.

\subsubsection{Performance indicators}

The model results from the sensitivity analysis were compared against performance indicators, including: (i) level of service indicators (i.e. compliance with the end use set-point temperature and the minimum hot water tank temperature); 
and (ii) energy performance indicators (i.e. annual energy consumption and energy intensity). Such indicators were also used to assess the performance of water heating systems by Vieira et al. [25].

Service indicators provide a measure of the performance of water heating systems with regards to their level of protection against Legionnaires' disease and the temperature comfort level for users, which are related to the compliance rates with the minimum hot water storage temperature and end use point set-point temperature, respectively. The minimum required temperature in hot water storage tanks was considered to be $55^{\circ} \mathrm{C}$, which is the temperature threshold to prevent Legionella sp. growth [44]. This threshold is lower than that suggested by the Plumbing Reference Guide of Australia $\left(60^{\circ} \mathrm{C}\right)$; yet it is more representative of the ASHPWH sample reviewed herein. The compliance rate with the end use set-point temperature was assessed taking into account the different values assigned to this parameter.

The energy performance indicators were used as a measure of the annual energy consumption and energy intensity of ASHPWH. These indicators were assessed as described in Section 2.2.

\section{Results and discussion}

\subsection{Empirical versus theoretical analyses}

The empirical and modelled energy consumption of the assessed ASHPWH followed a similar pattern, in which power-peaks occurred after water consumption events of approximately 50 l each at 6:35 am, 5:35 pm and 7:35 pm (Fig. 5).

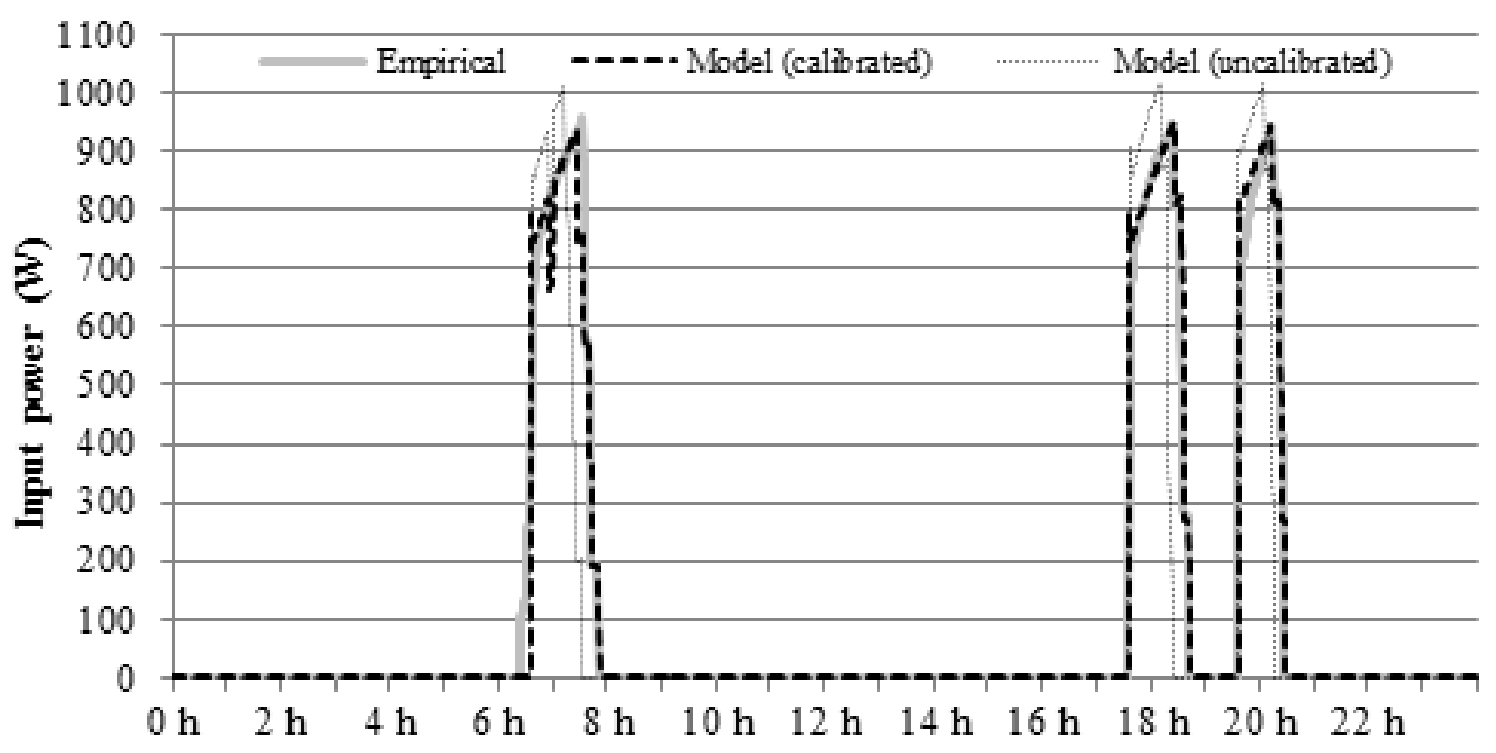

Fig. 5. Average energy consumption profile of the assessed ASHPWH from 24 to 30 of June 2014.

The input power-peak measured in the laboratory experiment had an average duration of approximately 1 hour and reached a maximum of $956 \mathrm{~W}$, which is close to the standard input power described by the manufacturer, i.e. $900 \mathrm{~W}$ (Table 1). In contrast, the maximum power-peak of models based on the ASHPWH technical specification (i.e. uncalibrated model) was $1018 \mathrm{~W}$ with an average duration of approximately $50 \mathrm{~min}$. This discrepancy led to a significant difference $\left(R^{2}=0.62\right)$ between empirical and uncalibrated model results when considering the energy consumption pattern of ASHPWH on a one minute basis. The limited accuracy of uncalibrated models to predict the energy consumption on a minute basis was more pronounced for power ranges under $600 \mathrm{~W}$ due to the low precision of models to ascertain when ASHPWH turn on and off. Nonetheless, on an hourly basis, the coefficient of determination 
between empirical data and uncalibrated model results for peak-power increased to $86 \%\left(R^{2}=0.86\right)$. This precision is within the acceptable accuracy level of simulations for building energy analysis [45,46].

After performing a calibration of the models, which consisted of adjusting input parameters to represent in a more accurate way the performance of the assessed ASHPWH against empirical data, the level of similarity between models and empirical energy consumption data on a one minute basis was equal to $96 \%\left(R^{2}=0.96\right)$. The enhancement of the calibrated compared to the uncalibrated model stems from its capacity to better represent the variation in energy consumption, which led to a more precise representation of energy consumption duration power-peaks after water supply events.

Moreover, the calibration process assisted with refining the selection of input parameters, which in turn promoted an enhancement of models to estimate the energy intensity of the ASHPWH. This process resulted in an enhancement of models to predict the energy intensity of ASHPWH, whereby the level of accuracy increased from $80 \%$ to $99 \%$ with the use of uncalibrated $\left(13.3 \mathrm{kWh} / \mathrm{m}^{3}\right)$ and calibrated $\left(16.7 \mathrm{kWh} / \mathrm{m}^{3}\right)$ models, respectively, in comparison to empirical data $\left(16.6 \mathrm{kWh} / \mathrm{m}^{3}\right)$. The input parameters for the uncalibrated and calibrated models are shown in Table 6.

\section{Table 6}

Input parameters of uncalibrated and calibrated models.

\begin{tabular}{lccc}
\hline & Uncalibrated & Calibrated & Difference (\%) \\
\hline COP $(\mathrm{W} / \mathrm{W})$ & 4.0 & 3.5 & -13 \\
Water heating capacity $(\mathrm{W})$ & 3600 & 2900 & -19 \\
Storage tank heat loss coefficient $(\mathrm{W} / \mathrm{K})$ & 1 & 2 & +100 \\
Storage tank capacity $(\mathrm{l})$ & 80 & 72 & -10 \\
Storage tank set-point temperature $\left({ }^{\circ} \mathrm{C}\right)$ & 60 & 60 & 0 \\
\hline
\end{tabular}

The input parameters for the calibrated model based on empirical data showed a declining trend in performance in comparison with the uncalibrated model based on the technical specification of the ASHPWH. This may indicate an optimistic bias of manufacturers when describing the overall performance of their products. For instance, like the results presented by Burch and Erickson [47], the results herein demonstrate that the actual storage capacity of hot water tanks is $10 \%$ less than the nominal capacity specified by the manufacturer.

Nonetheless, the differences between the calibrated and uncalibrated models may also indicate the contribution of other factors, which were simplified in the models. For instance, the discrepancy between the heat loss coefficient of the empirical and theoretical analyses may indicate that a significant proportion of heat loss takes place not only in the hot water tank surface, but also in pipe works off the hot water tank outlet. Therefore, the adopted heat loss coefficient of 2 $\mathrm{W} / \mathrm{K}$ for storage tanks in the calibrated model is equivalent to an additional $1 \mathrm{~W} / \mathrm{K}$ heat loss through the outlet pipe connection of the hot water tank added to the standard tank heat loss through the surface. Such a loss should not be mistaken by the standard pipe work heat losses during hot water distribution.

The measured hot water temperature variation at the hot water tank outlet during water heating was equal to the set-point temperature described by the manufacturer, i.e. $60^{\circ} \mathrm{C}$ with a $10^{\circ} \mathrm{C}$ dead band. Therefore, this parameter required no calibration.

\subsection{Sensitivity analysis}

\subsubsection{Variability of input parameters}


The technical specifications of ASHPWH listed in the SRES were reviewed, in which the average COP $(n=50)$, water heating capacity $(n=48)$ and hot water storage capacity $(n=109)$ were equal to $3.8 \mathrm{~W} / \mathrm{W}, 3.6 \mathrm{~kW}$ and $268 \mathrm{l}$, respectively (Table 7). The classes of input parameters calculated from these values are summarised in Table 8.

Table 7

Technical specifications of the ASHPWH sample from SRES.

\begin{tabular}{lccccc}
\hline & Sample size & Average & Median & Maximum & Minimum \\
\hline COP (W/W) & 50 & 3.8 & 3.9 & 4.5 & 2.8 \\
Water heating capacity (W) & 48 & 3,587 & 3,600 & 6,220 & 1,500 \\
Storage tank capacity (l) & 109 & 268 & 275 & 417 & 80 \\
Storage tank set-point temperature $\left({ }^{\circ} \mathrm{C}\right) *$ & 57 & 59 & 60 & 70 & 52 \\
\hline
\end{tabular}

Note: * Dead band of set-point temperatures assumed to be equal $10{ }^{\circ} \mathrm{C}$ as per experimental data.

The two categories of input parameters (i.e. technical specifications of ASHPWH and site-specific characteristics) presented a significant oscillation among the different energy performance classes as shown in Tables 8 and 9.

\section{Table 8}

Variability of ASHPWH technical specifications in relation to the energy performance classes.

\begin{tabular}{|c|c|c|c|c|c|c|}
\hline \multicolumn{2}{|c|}{ Energy performance class } & \multirow{2}{*}{$\begin{array}{c}\text { COP } \\
\text { (W/W) } \\
4.8\end{array}$} & \multirow{2}{*}{$\begin{array}{c}\begin{array}{c}\text { Water } \\
\text { heating } \\
\text { capacity } \\
\text { (W) } \\
7,306\end{array}\end{array}$} & \multirow{2}{*}{$\begin{array}{c}\begin{array}{c}\text { Storage } \\
\text { tank }\end{array} \\
\text { capacity (l) } \\
80\end{array}$} & \multirow{2}{*}{$\begin{array}{c}\begin{array}{c}\text { Storage tank } \\
\text { heat loss } \\
\text { coefficient } \\
\text { (W/K) }\end{array} \\
0.26\end{array}$} & \multirow{2}{*}{$\begin{array}{c}\begin{array}{c}\text { Storage tank } \\
\text { set-point } \\
\text { temperature }\left({ }^{\circ} \mathrm{C}\right)\end{array} \\
52\end{array}$} \\
\hline \multirow{5}{*}{$\begin{array}{c}\text { Nominal values } \\
\text { (uncalibrated) }\end{array}$} & Upper-extreme & & & & & \\
\hline & Upper-standard & 4.5 & 6,220 & 137 & 0.54 & 54 \\
\hline & Standard & 3.8 & 3,600 & 275 & 0.66 & 60 \\
\hline & Lower-standard & 2.8 & 1,500 & 417 & 0.78 & 67 \\
\hline & Lower-extreme & 2.4 & 630 & 476 & 0.98 & 70 \\
\hline \multirow{5}{*}{$\begin{array}{c}\text { Expected values } \\
\text { (calibrated) }\end{array}$} & Upper-extreme & 4.2 & 5,917 & 72 & 1.26 & 52 \\
\hline & Upper-standard & 3.9 & 5,038 & 123 & 1.54 & 54 \\
\hline & Standard & 3.3 & 2,916 & 248 & 1.66 & 60 \\
\hline & Lower-standard & 2.4 & 1,215 & 375 & 1.78 & 67 \\
\hline & Lower-extreme & 2.1 & 510 & 428 & 1.98 & 70 \\
\hline \multicolumn{2}{|c|}{ Variation nominal-expected } & $-3 \%$ & $-19 \%$ & $-10 \%$ & $+1 \mathrm{~W} / \mathrm{K}$ & $0 \%$ \\
\hline
\end{tabular}

Table 9

Variability of site specific conditions in relation to energy performance classes.

\begin{tabular}{|c|c|c|c|c|c|}
\hline \multicolumn{2}{|c|}{ Energy performance class } & $\begin{array}{c}\text { Cold water } \\
\text { temperature } \\
\left({ }^{\circ} \mathrm{C}\right)^{*}\end{array}$ & $\begin{array}{c}\text { Hot water end } \\
\text { use } \\
\text { temperature } \\
\left({ }^{\circ} \mathrm{C}\right) \\
\end{array}$ & $\begin{array}{c}\text { Hot water } \\
\text { consumption } \\
\text { pattern } \\
(\mathbf{l} / \mathbf{h h} / \text { day)** }\end{array}$ & $\begin{array}{c}\text { Time-distribution of } \\
\text { energy - electricity } \\
\text { interruption (hours/day) }\end{array}$ \\
\hline \multirow{5}{*}{$\begin{array}{c}\text { Expected } \\
\text { values }\end{array}$} & Upper-extreme & Avg +6 & 33 & 77 & 15 \\
\hline & Upper-standard & Avg +4 & 35 & 100 & 10 \\
\hline & Standard & Avg & 40 & 155 & 4 \\
\hline & Lower-standard & Avg -4 & 47 & 210 & 3 \\
\hline & Lower-extreme & Avg - 6 & 50 & 233 & 0 \\
\hline
\end{tabular}

Note: * Average (Avg) cold water temperatures vary across different cities and months. ** Hot water consumption pattern based on an occupancy rate of 2-3 people/household. 


\subsubsection{Influence of technical specifications}

The annual energy consumption of ASHPWH with different technical specifications varied considerably among the nine Australian cities assessed in the study, from approximately 520 to $1630 \mathrm{kWh} /$ year (Fig.6).

Variations in COP had the most significant $\left(p=4.8 \times 10^{-11}\right)$ effect on the energy consumption of ASHPWH among different technical specification parameters, promoting variations of 520-1630 kWh/year with an average of 1077 $\mathrm{kWh} /$ year and a median of $970 \mathrm{kWh} /$ year among the studied cities (Fig. 6a). The second most important parameter to energy consumption was the storage capacity of hot water tanks $\left(p=8.8 \times 10^{-10}\right)$, with a range of 421-1332 kWh/year, an average of $967 \mathrm{kWh} /$ year and a median of $970 \mathrm{kWh} /$ year (Fig. 6c); followed by the hot water tank set-point temperature $\left(p=8.3 \times 10^{-8}\right), 465-1305 \mathrm{kWh} /$ year, average of $994 \mathrm{kWh} /$ year and median of $975 \mathrm{kWh} /$ year (Fig. 6e); and the water heating capacity $\left(p=3.6 \times 10^{-8}\right)$, 596-1577 kWh/year, average of $1079 \mathrm{kWh} /$ year and median of 1041 $\mathrm{kWh} /$ year (Fig. 6b). The influence of the heat loss coefficient was not significant for a 95\% confidence interval ( $p>$ 0.1), varying between 543-1176 kWh/year with an average of $978 \mathrm{kWh} /$ year and median of $1005 \mathrm{kWh} /$ year (Fig. 6a). This indicates that the energy performance of ASHPWH would not be enhanced considerably by using the present typical offering of more efficient insulation materials than that currently used (e.g. 38mm glass fibre) under Australian weather conditions, albeit the use of thicker insulation on the distribution pipes is likely to promote energy savings.

The energy intensity presented a similar trend to the annual energy consumption when adopting different technical specifications for ASHPWH, ranging from 8 to $29 \mathrm{kWh} / \mathrm{m}^{3}$. This variation was influenced by different levels of technical specification parameters to the same extent as the oscillations observed for the total annual energy consumption of ASHPWH. This similarity is associated with the constant hot water consumption pattern (i.e. 155 l/hh/day) adopted to analyse the influence of technical specification parameters; nonetheless, the effect of different water consumption patterns was also assessed (see Section 3.2.3). The parameters with the greatest influence on the energy intensity of ASHPWH are presented in a descending order as follows: COP, storage tank capacity, storage tank set-point temperature and water heating capacity. The variation of the heat loss coefficient had an insignificant effect ( $p$ $>0.1$ ) on the energy intensity of ASHPWH for a 95\% confidence interval.

The level of service provided by ASHPWH, expressed as the capacity to maintain the set-point temperature of storage tanks and end use points, was not influenced by the COP and the heat loss coefficient taking into account a 95\% confidence interval $(p=1.0)$. Considering a COP variation, the level of compliance ranged between $45-66 \%$ (56 \% on average) and $77-100 \%$ (94\% on average) for the set-point temperature of hot water tanks and end use points, respectively. On a nationwide basis, the compliance with the standard end use point temperature $\left(40{ }^{\circ} \mathrm{C}\right)$ was not significantly influenced by the different classes of technical specification parameters for a level of confidence of $95 \%$. Technical specification parameters only caused a considerable decline in the level of compliance with the end use set-point temperature $\left(40^{\circ} \mathrm{C}\right)$ in colder cities, e.g. Canberra and Hobart. Considering these two cities alone, the variation in water heating capacity $\left(p=3.5 \times 10^{-4}\right)$ and the storage tank set-point temperature and capacity $(p=8.5 \times$ $10^{-3}$ ) promoted a significant oscillation in the compliance level with the end use point temperature, varying from 50 to $100 \%$. 


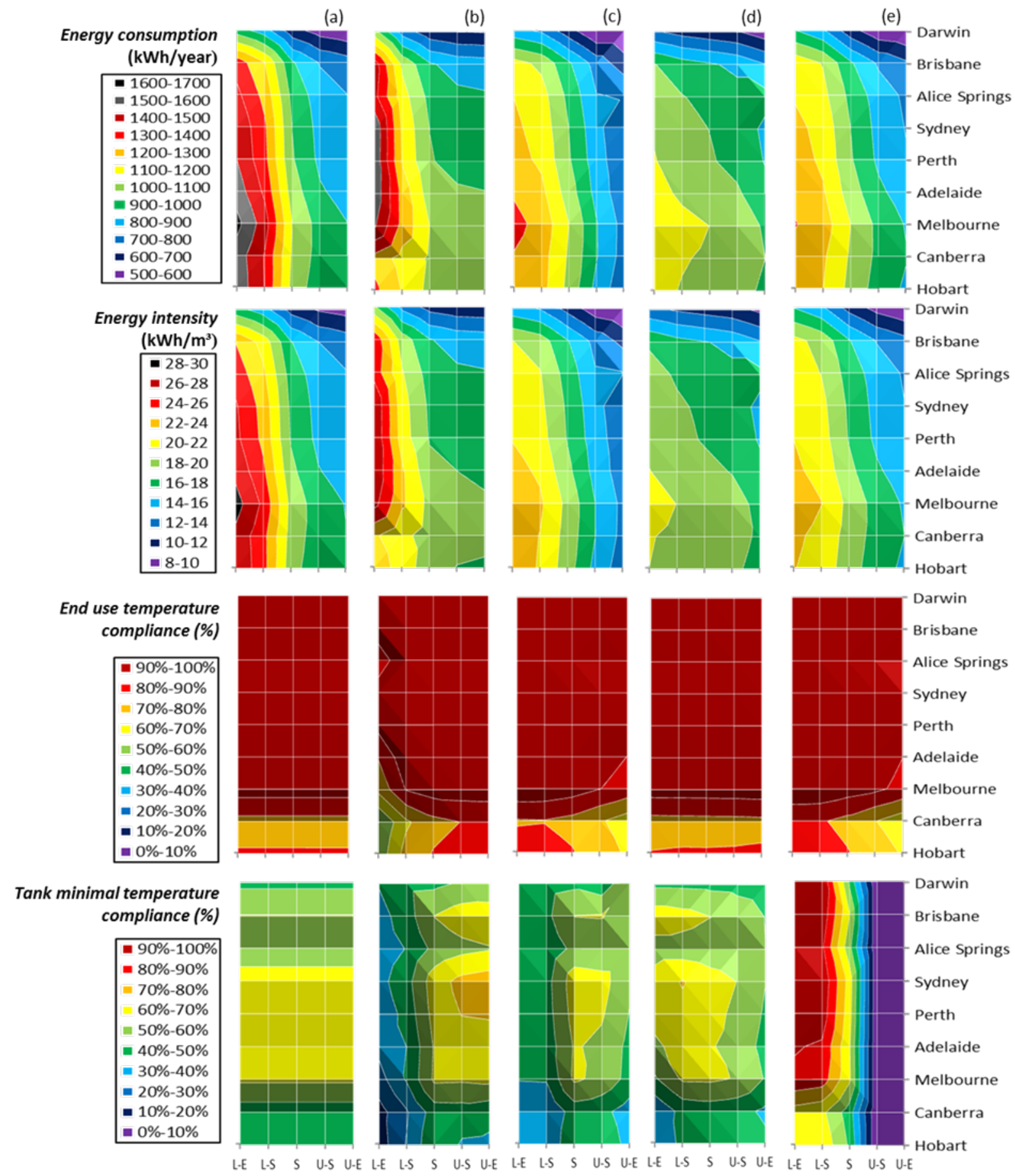

Fig. 6. Influence of ASHPWH technical specification parameters (COP (a), Water heating capacity (b), Storage tank capacity (c), Storage tank heat loss coefficient (d) and Storage tank set-point temperature (e)) on the Energy consumption , Energy intensity, End-use temperature and Storage tank temperature for different energy performance classes* across nine cities in Australia.

The levels of compliance with the minimum temperature threshold required to prevent Legionella sp. proliferation in hot water storage tanks $\left(>55^{\circ} \mathrm{C}\right)$ was not dependent on the COP of ASHPWH $(p=1.0)$; however, it varied considerably with other technical specification parameters, i.e. 0-100\% across different cities in Australia. Among the assessed technical specification parameters, storage tank set-point temperature caused the largest modification of the level of compliance with the minimum hot water temperature threshold $\left(p=1.7 \times 10^{-26}\right)$, raging between $0-100 \%(47 \%$ on average) (Fig. 6e). Despite the importance of the storage tank set-point temperature for inhibiting Legionella sp. growth, manufacturers and home owners tend to reduce the temperature to minimum levels $\left(55^{\circ} \mathrm{C}\right)$ so as to reduce the energy 
consumption of ASHPWH. This was observed among the reviewed ASHPWH, where most of the systems were configured by manufacturers to operate from 50 to $60^{\circ} \mathrm{C}$ in order to maintain an average temperature of $55^{\circ} \mathrm{C}$. However, among the reviewed ASHPWH there were heat pumps with a thermostat set-point temperature equal to $52^{\circ} \mathrm{C}$. Although this system may meet hot water requirements at end use points at a lower energy consumption requirement than systems set to $60^{\circ} \mathrm{C}$, it may promote health risks associated with the proliferation of Legionella sp. On the other hand, the elevation of the storage tank set-point temperature from 60 to $70{ }^{\circ} \mathrm{C}$ gave rise to compliance rates of $90-100 \%$ with the minimum temperature threshold across Australia.

The water heating capacity also influenced the levels of compliance with the minimum hot water storage temperature ( $p$ $\left.=6.9 \times 10^{-8}\right)$. A decrease in the heating capacity led to a decline in the levels of compliance with this parameter of $15-$ $75 \%$ with an average of $49 \%$ and median of $47 \%$ nationwide (Fig. $6 \mathrm{~b}$ ). Moreover, the storage capacity of hot water tanks also promoted a significant variation in the capacity of ASHPWH to maintain hot water at the minimum temperature threshold ( $p=8.9 \times 10^{-5}$ ), ranging between 30-66\% (48\% on average) (Fig. 6c). In general, the levels of compliance with the minimum temperature threshold for hot water tanks were greater when using the standard hot water tank size (275 l) for the standard hot water consumption pattern (155 l/hh/day) with an average compliance level of 56\% against $42 \%$ for oversized tanks (e.g. 417 and 476 l) and 48\% for undersized tanks (80 l). This is mainly attributed to both a reduced resilience to maintain high temperatures $\left(\geq 55^{\circ} \mathrm{C}\right)$ after water consumption events in undersized tanks, and an excessive stagnation of hot water with a slow decline of temperatures between the lower range of the standard set-point temperature $\left(50-55^{\circ} \mathrm{C}\right)$ in oversized tanks. The assessed range of heat loss coefficients did not demonstrate a significant influence on the level of compliance with the minimum hot water tank set-point temperature $(p=0.12)$ for a $90 \%$ confidence interval.

\subsubsection{Influence of site-specific conditions}

All site-specific characteristics had considerable influence on the energy consumption of ASHPWH across Australia, ranging from approximately 500 to $1300 \mathrm{kWh} /$ year (Fig. 7). The hot water consumption pattern and end use temperature were the two site-specific characteristics with the largest influence on the energy consumption of ASHPWH, i.e. $p=2.0 \times 10^{-8}$ and $p=1.8 \times 10^{-7}$, respectively. The first promoted an oscillation of the energy consumption between 528-1358 kWh/year among studied cities (Fig. 7c); while the latter influenced the energy consumption to vary between $473-1318 \mathrm{kWh} /$ year (Fig. 7b). The cold water temperature supply $\left(p=1.3 \times 10^{-4}\right)$ and the time-distribution of energy according to the electricity tariff $\left(p=1.0 \times 10^{-4}\right)$ also significantly influenced the variation in energy consumption among the assessed cities, ranging between 498-1238 and 580-1100 kWh/year, respectively.

The energy intensity of ASHPWH showed a strong relationship with site-specific characteristics. This parameter varied from around $8 \mathrm{kWh} / \mathrm{m}^{3}$ in a tropical climate (Darwin) to $30 \mathrm{kWh} / \mathrm{m}^{3}$ in cool temperate climates (Melbourne, Canberra and Hobart). Apart from the weather conditions, energy intensity was mostly influenced by the hot water consumption pattern $\left(p=1.4 \times 10^{-12}\right)$ and temperature $\left(p=1.8 \times 10^{-7}\right)$, ranging between 8.9-30.0 and 8.4-23.3 $\mathrm{kWh} / \mathrm{m}^{3}$, respectively. Variation in cold water temperature also had a significant influence on the overall performance of ASHPWH $(p=1.3 \times$ $10^{-4}$ ), oscillating between $8.8-21.9 \mathrm{kWh} / \mathrm{m}^{3}$. The time-distribution of energy had a neutral effect when considering the use of 3 to 4 hours electricity interruption during peak hours, promoting a variation of $10.2-19.4 \mathrm{kWh} / \mathrm{m}^{3}$; although, long electricity interruptions associated with the use of the maximum controlled tariff (TC3) and night off-peak tariff (TN) had a significant effect on the energy intensity of ASHPWH due to an overall decline in the hot water temperature in storage tanks during electricity interruptions. As a result, the energy intensity levels had an average reduction from $17.3 \mathrm{kWh} / \mathrm{m}^{3}$ with standard tariff to $12.3 \mathrm{kWh} / \mathrm{m}^{3}$ with night-off peak tariff (Fig. 7d). On average, the time-distribution of energy significantly influenced the energy intensity of ASHPWH $\left(p=1.0 \times 10^{-4}\right)$. 
Energy consumption (kWh/year)

- 1600-1700

1500-1600

- 1400-1500

- 1300-1400

- 1200-1300

1100-1200

= 1000-1100

= 900-1000

= 800-900

- 700-800

- 600-700

- 500-600

Energy intensity

$\left(\mathrm{kWh} / \mathrm{m}^{3}\right)$

- 28-30

- 26-28

- 24-26

= 22-24

20-22

=18-20

= 16-18

= 14-16

ㅁ 12-14

- 10-12

= 8-10

\section{End use temperature} compliance (\%)

- 90\%-100\%

- $80 \%-90 \%$

$=70 \%-80 \%$

60\%-70\%

$=50 \%-60 \%$

= $40 \%-50 \%$

$=30 \%-40 \%$

- $20 \%-30 \%$

- $10 \%-20 \%$

- $0 \%-10 \%$

Tank minimal temperature

compliance (\%)

\begin{tabular}{|c|}
\hline$=90 \%-100 \%$ \\
$=80 \%-90 \%$ \\
$=70 \%-80 \%$ \\
$60 \%-70 \%$ \\
$=50 \%-60 \%$ \\
$=40 \%-50 \%$ \\
$=30 \%-40 \%$ \\
$=20 \%-30 \%$ \\
$=10 \%-20 \%$ \\
$=0 \%-10 \%$ \\
\hline
\end{tabular}

(a)

(b)
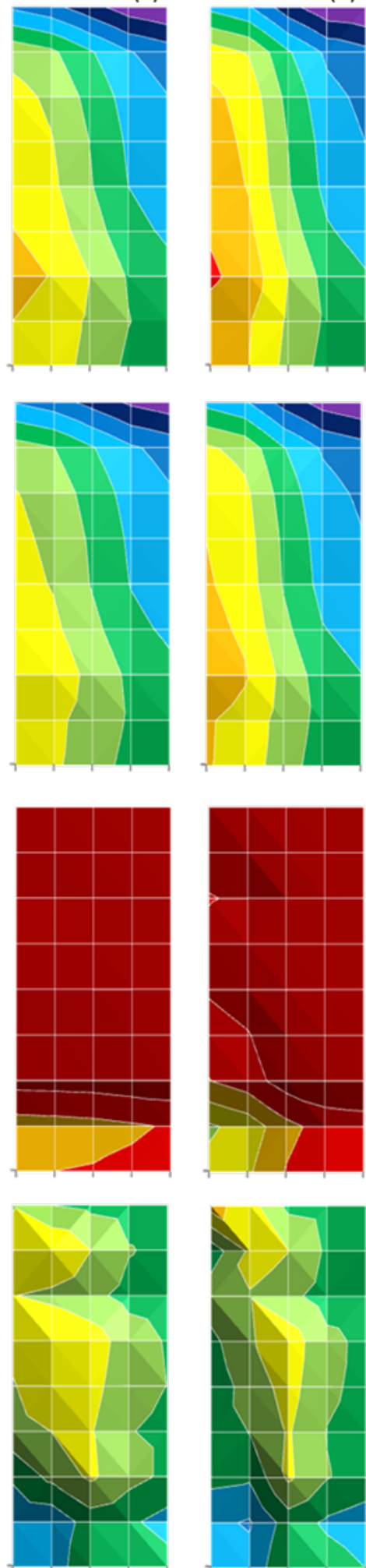

(c)
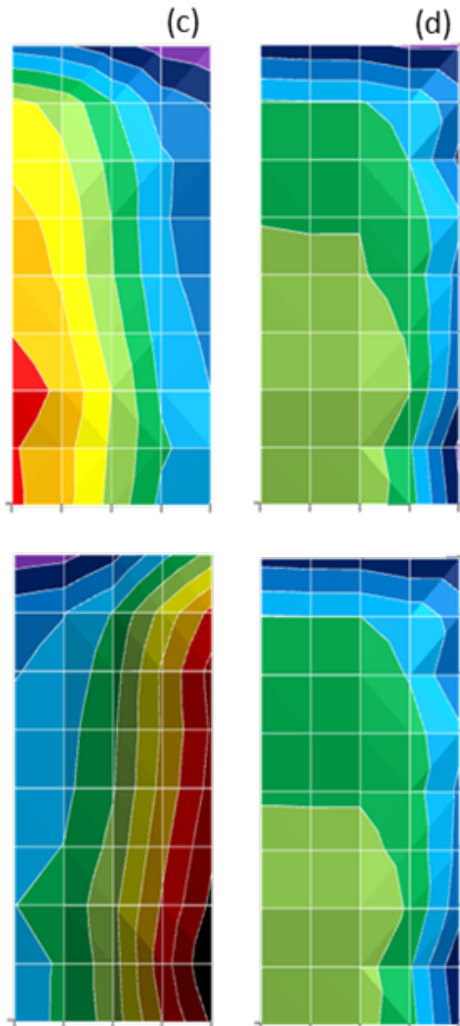

(d)

Darwin

Brisbane

Alice Springs

Sydney

Perth

Adelaide

Melbourne

Canberra

Hobart
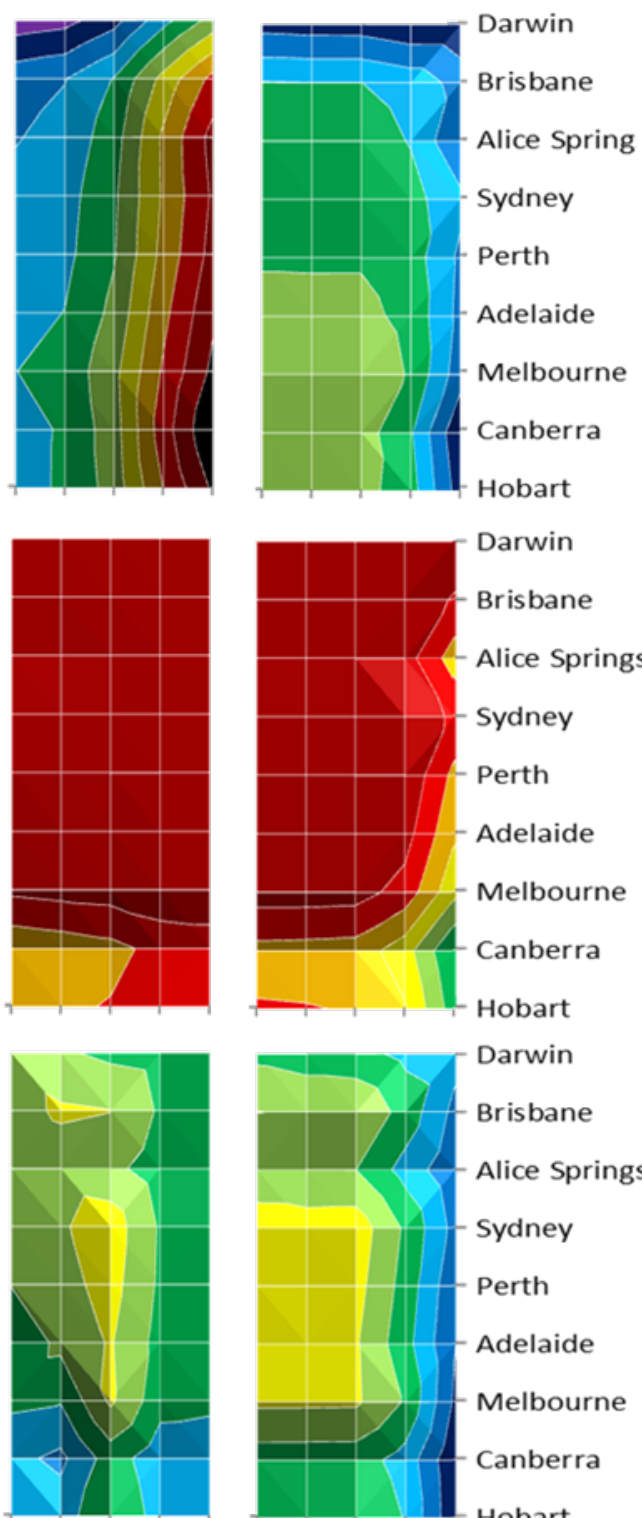

- Darwin

Brisbane

Alice Springs

Sydney

Perth

Adelaide

Melbourne

Canberra

Hobart

L-E L-S S S U.S U.E L-E L-S S S U-S U.E L-E L-S S U.S U.E TS TC1 TC2 TC3 TN

Fig. 7. Influence of site-specific parameters (Cold Water Temperature (a), Hot Water end use temperature (b) and Hot Water Consumption Pattern (c)) and time -distribution of energy according to the electricity tariff (d) on the Energy consumption, Energy intensity, End-use temperature and Storage tank temperature of ASHPWH for different energy performance classes* and electricity tariffs** across nine cities in Australia. 
The compliance rate with the hot water end use temperature was usually independent of site-specific characteristics, except for ASHPWH in cool temperature climates (i.e. Canberra and Hobart), where levels of compliance declined as low as $40 \%$.

The time-distribution of energy promoted a significant variation in the level of compliance with the end use temperature ( $p=0.002$ ) mostly due to low compliance rates of ASHPWH connected to the night off-peak tariff in cooler cities (e.g. 40\% in Canberra and 45\% in Hobart (Fig. 7d)). The overall compliance with the end use temperature also varied significantly by taking into account different set-point temperatures $(p=0.04)$ as a result of the reduction of compliance in cooler regions (e.g. 58\% in Canberra and 63\% in Hobart). The cold water temperature and the water consumption pattern did not influence the level of compliance with the end use temperature when considering a 95\% confidence interval; nonetheless, these parameters still promoted a respective variation between $75-100 \%$ and $72-100 \%$ in compliance levels.

The temperature of the hot water in storage tanks was usually higher under standard conditions, demonstrating variation in the level of compliance with the minimum temperature set-point $\left(55^{\circ} \mathrm{C}\right)$ to prevent Legionella sp. The time-distribution of energy associated with different electricity tariff schemes was the factor with the greatest influence on levels of compliance with the minimum storage tank temperature $\left(p=7.9 \times 10^{-13}\right)$, leading to an oscillation between $11-66 \%$ in compliance levels. For instance, the utilisation of night off-peak tariffs caused an average decrease of $30 \%$ in the level of compliance with the minimum temperature threshold for storage tanks in comparison to tariffs with short electricity supply interruption ( $\leq 4$ hours). The latter tariff type (TS, TC1 and TC2) did not considerably affect the compliance rates with the minimum storage tank temperature, promoting an insignificant variation of less than $1 \%$.

Hot water consumption patterns had a considerable influence $\left(p=8.8 \times 10^{-3}\right)$ on the minimum storage tank temperature set-point, giving rise to an oscillation between 28-66\% (48\% on average) (Fig. 7c). In general, the increases and decreases in hot water consumption in comparison to the standard pattern (i.e. $155 \mathrm{l} / \mathrm{hh} / \mathrm{d}$ ) were associated with a decline in the compliance level due to both limitations in meeting hot water demand, and excessive stagnation of hot water at $50-55^{\circ} \mathrm{C}$, respectively. Variation in end use temperature set-point $\left(p=7.4 \times 10^{-2}\right)$ and cold water temperature $\left(p=1.7 \times 10^{-1}\right.$ ) had no influence on the level of compliance with the minimum storage tank temperature for a 95\% confidence interval, in which such parameters promoted a variation in compliance levels between 15-29\% and 13-23\% among the studied cities, respectively.

\section{Conclusions, recommendations and future research directions}

\subsection{Conclusions}

The current study examined the influence of different technical specifications and site-specific conditions on the performance of ASHPWH in residential buildings across nine cities in Australia. The study was carried out by employing sensitivity analysis through theoretical models calibrated with empirical measurements. The main conclusions drawn from the results include:

- $\quad$ The COP and the storage tank capacity are the factors that most influence the energy consumption of ASHPWH, although hot water end use temperature and hot water consumption patterns of households also have a key part to play in energy consumption patterns of ASHPWH;

- The water heating capacity and storage tank set-point temperature, which are usually taken for granted in the selection of ASHPWH, have a major role in the energy consumption of ASHPWH;

- The largest oscillation in the energy intensity (unit of energy per unit of water supplied) was associated with a variation in the hot water consumption pattern. Patterns with low hot water consumption gave rise to an increase in the energy intensity due to hot water reheating events; 
- Among the assessed ASHPWH sample, the usual set-point temperature band $\left(50-60{ }^{\circ} \mathrm{C}\right)$ of hot water tanks described in the technical specifications was associated with a compliance level with the minimum hot water storage temperature $\left(55^{\circ} \mathrm{C}\right)$ ranging from 45 to $66 \%$, whereas extreme standard values for the upper temperature threshold of 52 and $67^{\circ} \mathrm{C}$ led to average compliance levels of 0 and 85\%, respectively;

- The use of a different time-distribution of energy according to the electricity tariff promoted a neutral effect on the compliance level with the minimum storage tank temperature when using controlled tariffs with a maximum electricity supply interruption of 4 hours, although tariffs with a longer interruption (i.e. 10 and 15 hours) were associated with a significant reduction in compliance levels;

- The influence of technical specifications and site-specific conditions on the energy performance of ASHPWH is reduced in warmer climate conditions, enabling the use of a wider range of ASHPWHs.

\subsection{Recommendations}

Taking into account the conditions assessed in the present study, the energy efficiency and the level of service provided by ASHPWH could be enhanced through the adoption of the following recommendations:

- The classification or ranking of ASHPWH into energy efficiency rebate schemes and labelling programmes should be based not only on the COP, but also on the water heating capacity and storage tank set-point temperature;

- Careful consideration of the ideal ASHPWH specification for a household size based on local hot water consumption patterns should be a key component of the framework of energy efficiency rebate schemes and labelling programmes;

- The use of SHPWH has to be preceded by a careful selection of technical specifications in order to prevent excessive non-compliance events with required levels of service specially in cooler regions;

- Oversizing of ASHPWH should be avoided in order to prevent an increase in the energy intensity, as well as a decrease in the level of compliance with the minimum set-point temperature of storage tanks;

- The enhancement of the energy efficiency of ASHPWH by means of a reduction of the set-point temperature of storage tanks should be limited to the extent where the inactivation of Legionella sp. is not jeopardised;

- Despite the benefits of using intermittent electricity supply (e.g. diversion of power-peaks and cheaper electricity tariffs), their use should be restricted to short interruption times ( $<5$ hours) in order to avoid extensive periods of non-compliance with the minimum temperature required to prevent Legionella sp. proliferation in hot water storage tanks.

\subsection{Future research directions}

The following future research directions are foreseen as fundamental pieces of information to narrow the knowledge gap about ASHPWH in residential buildings, and in turn enhance both the energy efficiency of ASHPWH and the effectiveness of strategic national energy efficiency programmes:

- On-site monitoring of ASHPWH in residential buildings in order to gain knowledge of potential variation in their level of performance over time taking into consideration energy efficiency and level of service parameters;

- Comprehensive assessment of the influence of ASHPWH set-point temperature on the proliferation of Legionella sp. in residential buildings in order to identify potential health risks to households;

- Economic feasibility study of ASHPWH so as to determine key factors (e.g. outlay cost, life-cycle maintenance cost, system life-time, role of government rebate programmes, etc.) limiting their widespread use by the residential sector. 


\section{Acknowledgements}

The authors acknowledge the company Hot Water Gold Coast for being the industry pattern in this project, and the personnel from the School of Engineering Laboratory at Griffith University in the Gold Coast campus for assisting with the technical aspects of the laboratory experiment.

\section{References}

[1] L.G. Swan, V.I. Ugursal, Modeling of end-use energy consumption in the residential sector: A review of modeling techniques, Renewable and Sustainable Energy Reviews 13 (2009) 1819-1835.

[2] N. Khanna, D. Fridley, N. Zhou, J. Ke, Implications of maximizing China 's technical potential for residential end-use energy efficiency : A 2030 outlook from the bottom-up, Lawrence Berkeley National Laboratory, University of California, Berkeley, 2013.

[3] H. Singh, A. Muetze, P.C. Eames, Factors influencing the uptake of heat pump technology by the UK domestic sector, Renewable Energy 35 (2010) 873-878.

[4] J. Min, Z. Hausfather, Q.F. Lin, A High-Resolution Statistical Model of Residential Energy End Use Characteristics for the United States, Journal of Industrial Ecology 14 (2010) 791-807.

[5] X. Liu, S. Lau, H. Li, Optimization and analysis of a multi-functional heat pump system with air source and gray water source in heating mode, Energy and Buildings 69 (2014) 1-13.

[6] E. Ghisi, S. Gosch, R. Lamberts, Electricity end-uses in the residential sector of Brazil, Energy Policy 35 (2007) 4107-4120.

[7] L. Pérez-Lombard, J. Ortiz, C. Pout, A review on buildings energy consumption information, Energy and Buildings 40 (2008) 394-398.

[8] F. Alam, T. Theos, A New Generation Energy Efficient Residential House in Australia, Procceedings of the4th BSME-ASME International Conference on Thermal Energineering 27-29 December, 2008, Dhaka, Bangradesh, 2008: pp. 710-718.

[9] A. Stafford, D. Lilley, Predicting in situ heat pump performance: An investigation into a single ground-source heat pump system in the context of 10 similar systems, Energy and Buildings 49 (2012) 536-541.

[10] E.P. Johnson, Air-source heat pump carbon footprints: HFC impacts and comparison to other heat sources, Energy Policy. 39 (2011) 1369-1381.

[11] A. Hepbasli, Y. Kalinci, A review of heat pump water heating systems, Renewable and Sustainable Energy Reviews 13 (2009) 1211-1229.

[11] P. Blazey, P. Gillies, Sustainable housing in Australia - Fisical incetives and regulatory regimes - Current developments - Policies for the future, Macquarie University, Sydney, 2008. 
[12] P. Blazey, P. Gillies, Sustainable housing in Australia - Fisical incetives and regulatory regimes - Current developments - Policies for the future, Sydney, 2008.

[13] A. Sözen, D. Altıparmak, H. Usta, Development and testing of a prototype of absorption heat pump system operated by solar energy, Applied Thermal Engineering 22 (2002) 1847 - 1859.

[14] X. Ma, J. Chen, S. Li, Q. Sha, A. Liang, W. Li, et al., Application of absorption heat transformer to recover waste heat from a synthetic rubber plant, Applied Thermal Engineering 23 (2003) 797-806.

[15] Y. Yao, Y. Jiang, S. Deng, Z. Ma, A study on the performance of the airside heat exchanger under frosting in an air source heat pump water heater/chiller unit, International Journal of Heat and Mass Transfer 47 (2004) 37453756.

[16] Y. Ding, Q. Chai, G. Ma, Y. Jiang, Experimental study of an improved air source heat pump, Energy Conversion and Management 45 (2004) 2393-2403.

[17] F.B. Gorozabel Chata, S.K. Chaturvedi, a. Almogbel, Analysis of a direct expansion solar assisted heat pump using different refrigerants, Energy Conversion and Management 46 (2005) 2614-2624.

[18] a. a. Argiriou, C. a. Balaras, S. Kontoyiannidis, E. Michel, Numerical simulation and performance assessment of a low capacity solar assisted absorption heat pump coupled with a sub-floor system, Solar Energy 79 (2005) 290-301.

[19] O. Ozgener, A. Hepbasli, Modeling and performance evaluation of ground source (geothermal) heat pump systems, Energy Buildings 39 (2007) 66-75.

[20] C. Keil, S. Plura, M. Radspieler, C. Schweigler, Application of customized absorption heat pumps for utilization of low-grade heat sources, Applied Thermal Engineering 28 (2008) 2070-2076.

[21] G.L. Morrison, T. Anderson, M. Behnia, Seasonal performance rating of heat pump water heaters, Solar Energy 76 (2004) 147-152.

[22] N.J. Kelly, J. Cockroft, Analysis of retrofit air source heat pump performance: Results from detailed simulations and comparison to field trial data, Energy Buildings 43 (2011) 239-245.

[23] M. Piechowski, Heat and mass transfer model of a ground heat exchanger: validation and sensitivity analysis, International Journal of Energy Research 22 (1998) 965-979.

[24] D. Jenkins, R. Tucker, M. Ahadzi, R. Rawlings, The performance of air-source heat pumps in current and future offices, Energy Buildings 40 (2008) 1901-1910.

[25] A.S. Vieira, C.D. Beal, R. A. Stewart, Residential water heaters in Brisbane, Australia: Thinking beyond technology selection to enhance energy efficiency and level of service, Energy and Buildings 82 (2014).

[26] G. Buckman, M. Diesendorf, Design limitations in Australian renewable electricity policies, Energy Policy. 38 (2010) 3365-3376. 
[27] J. Carlo, R. Lamberts, Development of envelope efficiency labels for commercial buildings: Effect of different variables on electricity consumption, Energy and Buildings 40 (2008) 2002-2008.

[28] M.M. Hassan, Y. Beliveau, Modeling of an integrated solar system, Building and Environment 43 (2008) 804 810.

[29] Q.-Y. Li, Q. Chen, X. Zhang, Performance analysis of a rooftop wind solar hybrid heat pump system for buildings, Energy and Buildings 65 (2013) 75-83.

[30] D. G. Sanchez, B. Lacarrière, M. Musy, B. Bourges, Application of sensitivity analysis in building energy simulations: Combining first- and second-order elementary effects methods, Energy and Buildings 68 (2014) $741-750$.

[31] US-DOE, EnergyPlus Engineering Reference, v8.1 ed., The Board of Trustees of the University of Illinois and the Regents of the University of California through the Ernest Orlando Lawrence Berkeley National Laboratory, Berkeley, USA, 2013.

[32] F.P. Incropera, D.P. Dewitt, T.L. Bergman, A.S. Lavine, Fundamentals of Heat and Mass Transfer, 6th ed., John Wiley \& Sons Inc., 2007.

[33] S.A. Omer, S.B. Riffat, G. Qiu, Thermal insulations for hot water cylinders : a review and a conceptual evaluation, Building Services Engineering Research and Technology 28 (2007) 275-293.

[34] Y.W. Li, R.Z. Wang, J.Y. Wu, Y.X. Xu, Experimental performance analysis on a direct-expansion solar-assisted heat pump water heater, Applied Thermal Engineering 27 (2007) 2858-2868.

[35] R. Hendron, R. Anderson, C. Christensen, M. Eastment, P. Reeves, Development of an Energy Savings Benchmark for All Residential End-Uses, Proceedings of the SIMBUILD2004 Conference, Boulder, Colorado, August 4-6, 2004: pp. 1-11.

[36] S. Kenway, A. Blinks, J. Bors, F. Pamminger, P. Lant, B. Head, et al., Understanding and managing water-related energy use in Australian households, Water 41 (2014) 184-188.

[37] Australia, Plumber Reference Guide - Solar \& Heat Pump Hot Water Systems, Department of Climate Change and Energy Efficiency - Commonwealth of Australia, 2010.

[38] ABS, Year Book Australia, 2009-2010: Households and Families, Australian Bureau of Statistics (2010). http://www.abs.gov.au/AUSSTATS/abs@.nsf/lookup/916F96F929978825CA25773700169C65?opendocument (accessed May 10, 2014).

[39] I.R. Pillai, R. Banerjee, Methodology for estimation of potential for solar water heating in a target area, Solar Energy 81 (2007) 162-172.

[40] X. Li, W. Wu, X. Zhang, W. Shi, B. Wang, Energy saving potential of low temperature hot water system based on air source absorption heat pump, Applied Thermal Engineering 48 (2012) 317-324.

[41] R.J. Moffat, Contributions to the Theory of Single-Sample Uncertainty Analysis, Transactions of the American Society of Mechanical Engineers 104 (1982) 1-9. 
[42] S.D. Phillips, K.R. Eberhardt, B. Parry, Guidelines for expressing the uncertainty of measurement results containing uncorrected bias, Journal of Research of the National Institute of Standards and Technology 102 (1997) 577-585.

[43] E. Mathioulakis, G. Panaras, V. Belessiotis, Uncertainty in estimating the performance of solar thermal systems, Solar Energy 86 (2012) 3450-3459.

[44] A. Serrano-Suárez, J. Dellundé, H. Salvadó, S. Cervero-Aragó, J. Méndez, O. Canals, et al., Microbial and physicochemical parameters associated with Legionella contamination in hot water recirculation systems., Environmental Science and Pollution Research 20 (2013) 5534-44.

[45] K. Xu, Assessing the minimum instrumentation to well tune existing medium sized office building energy models, Pennsylvania State University, Pennsylvania, 2012.

[46] R. Judkoff, D. Wortman, B.O’Doherty, J. Burch, A Methodology for Validating Building Energy Analysis Simulations A Methodology for Validating Building Energy Analysis Simulations, National Renewable Energy Laboratory, Colorado, 2008.

[47] J. Burch, P. Erickson, Using ratings data to derive simulation-model inputs for storage-tank water heaters, Proceedings of the Solar 2004 Conference Including Procceings of the $33^{\text {rd }}$ ASES Annual Conference and Proceedings of the $29^{\text {th }}$ National Passive Solar Conference,.11-14 July 2004, Portland, Oregon, 2004: pp. 394398. 